\title{
Human dendritic cell functional specialization in steady-state and inflammation
}

\section{Arjan Boltjes and Femke van Wijk*}

Laboratory for Translational Immunology, Department of Pediatric Immunology, University Medical Center Utrecht, Utrecht, Netherlands

\section{Edited by:}

Marianne Boes, University Medical

Centre Utrecht, Netherlands

\section{Reviewed by:}

Masaaki Murakami, Osaka University, Japan

Susan Kovats, Oklahoma Medical

Research Foundation, USA

${ }^{*}$ Correspondence:

Femke van Wijk, Laboratory for Translational Immunology,

Department of Pediatric Immunology, University Medical Center Utrecht,

Lundlaan 6, Utrecht 3508 GA,

Netherlands

e-mail:f.vanwijk@umcutrecht.nl
Dendritic cells (DC) represent a heterogeneous population of antigen-presenting cells that are crucial in initiating and shaping immune responses. Although all DC are capable of antigen-uptake, processing, and presentation to T cells, DC subtypes differ in their origin, location, migration patterns, and specialized immunological roles. While in recent years, there have been rapid advances in understanding DC subset ontogeny, development, and function in mice, relatively little is known about the heterogeneity and functional specialization of human DC subsets, especially in tissues. In steady-state, DC progenitors deriving from the bone marrow give rise to lymphoid organ-resident DC and to migratory tissue DC that act as tissue sentinels. During inflammation additional DC and monocytes are recruited to the tissues where they are further activated and promote T helper cell subset polarization depending on the environment. In the current review, we will give an overview of the latest developments in human DC research both in steady-state and under inflammatory conditions. In this context, we review recent findings on DC subsets, DC-mediated cross-presentation, monocyte-DC relationships, inflammatory DC development, and DCinstructed T-cell polarization. Finally, we discuss the potential role of human DC in chronic inflammatory diseases.

Keywords: dendritic cells, subsets, monocytes, humans, inflammation, inflammatory dendritic cells, functional specialization, skin

\section{INTRODUCTION}

Dendritic cells (DC) have highly effective mechanisms to detect and capture antigens and to subsequently determine the magnitude and quality of adaptive immune responses. They are the most potent antigen-presenting cells (APC) in promoting activation of naïve $\mathrm{T}$ cells.

In the past years, major advances have been made in understanding mouse DC ontogeny, molecular development, and function. Human DC immunobiology, however, is only beginning to be understood. Several recent reviews have aligned data on human and mouse DC networks $(1,2)$ and have highlighted similarities, parallels, and differences. In the current review, we will put the human DC subsets in the spotlight and focus on recent advances in human DC development and functional specialization, both in steady-state and in inflammatory conditions.

\section{HUMAN DC SUBSETS}

Dendritic cells are heterogeneous and can be sub-classified based on anatomical location, origin, and function. After exiting the bone marrow into the blood, DC progenitors give rise to resident and migratory DC following final in situ differentiation. Resident DC are localized in lymphoid tissue (LT) where they take up antigen from the lymph and bloodstream and present it to local T cells. Non-lymphoid tissue (NLT) DC constitutively migrate from the tissues to the lymph nodes where they present tissue-derived antigens to $\mathrm{T}$ cells. In peripheral blood, three main DC subsets have been acknowledged within the HLA-DR ${ }^{+}$lineage negative fraction that can be identified based on their surface marker expression: plasmacytoid DC (pDC) and two types of conventional DC (cDC); CD1c/BDCA- ${ }^{+} \mathrm{cDC}$, and CD141/BDCA$3^{+} \mathrm{cDC}(3,4)$ (Figure 1). These subsets can also be found in spleen and tonsils (5-7). Hierarchical clustering of mouse LN and human blood DC subsets based on genome-wide expression profiling demonstrated clustering of human $\mathrm{pDC}$ with mouse $\mathrm{pDC}$, $\mathrm{CD}_{141}{ }^{+} \mathrm{cDC}$ with mouse $\mathrm{CD} 8 \alpha^{+} \mathrm{DC}$, and human $\mathrm{CD} 1 \mathrm{c}^{+} \mathrm{cDC}$

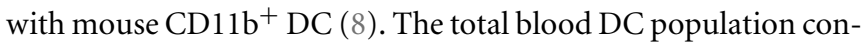
sists of about $5-10 \% \mathrm{CD} 141^{+} \mathrm{CDC}$ while the remainder is divided into equal parts pDC and $\mathrm{CD} 1 \mathrm{c}^{+} \mathrm{cDC}(9)$.

Segura and colleagues recently demonstrated that resident LN DC subtypes also phenotypically correspond to blood pDC, $\mathrm{CD}^{+}{ }^{+}$, and $\mathrm{CD} 141^{+} \mathrm{CDC}(10)$. Whereas $\mathrm{CDC}$ are thought to reach the LN after trafficking from peripheral tissue via afferent lymphatic vessels, pDC have been described to migrate directly from the blood to the LN via high endothelial venules (HEV) (11).

In general, NLT DC have a more activated phenotype expressing higher levels of co-stimulatory molecules than their blood counterparts. In the skin, lung, and liver two cDC subsets identical to $\mathrm{CD} 1 \mathrm{c}^{+}$and $\mathrm{CD} 141^{+}$blood $\mathrm{cDC}$ have been identified (12, $13)$, whereas pDC are absent in tissues under steady-state conditions. Human $\mathrm{CD} 1 \mathrm{c}^{+}$and $\mathrm{CD} 141^{+}$tissue-resident $\mathrm{DC}$ are related to mouse tissue-resident $\mathrm{CD} 11 \mathrm{~b}^{+}$and $\mathrm{CD}_{103^{+}} \mathrm{DC}$, respectively (12). In addition to $\mathrm{CDC}$, human tissues also harbor migratory CD14 ${ }^{+}$DC, which are not found in the blood $(12,13)$ and do not have an identified murine equivalent. However, CD14 ${ }^{+}$NLT DC display an intermediate phenotype expressing both macrophage and DC markers, and the transcriptomic expression profiles of 


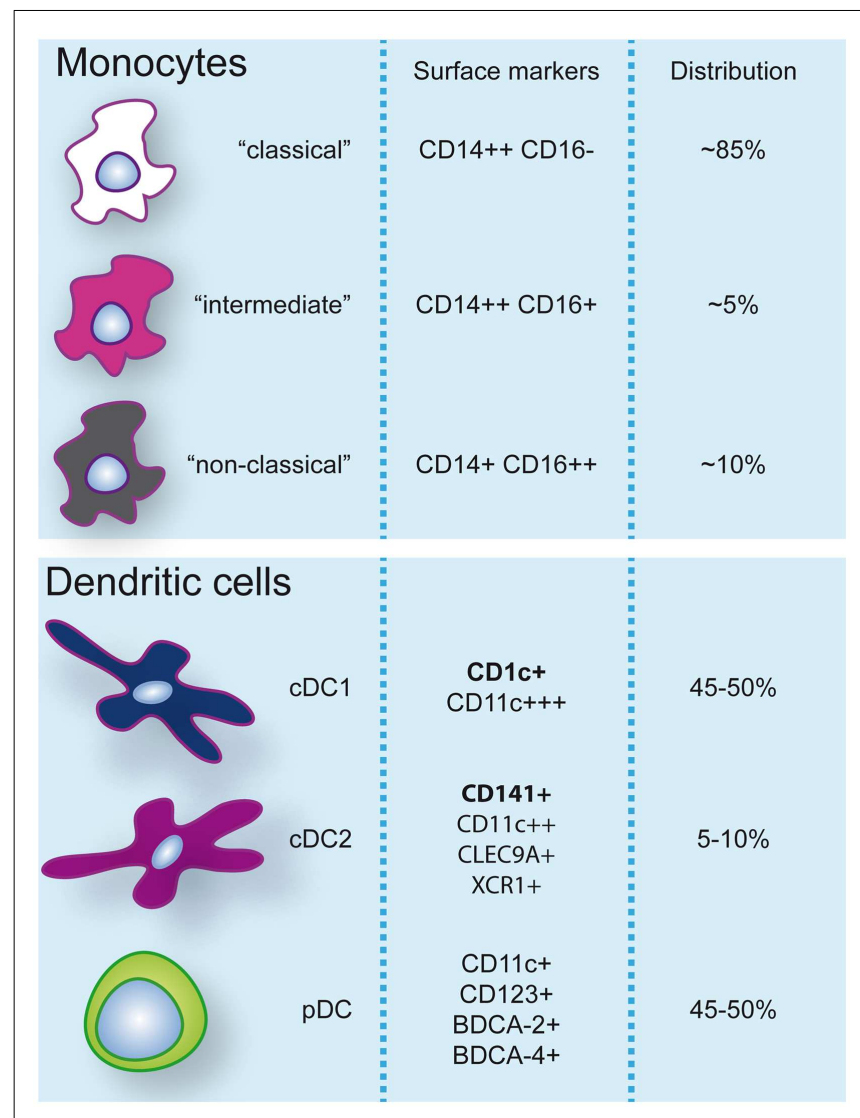

FIGURE 1 | Monocyte and dendritic cell populations in human peripheral blood during steady-state conditions. Expression of markers commonly used to identify and discern these populations are indicated. Additionally, frequencies (\%) of monocyte subsets within the monocyte pool and dendritic cells within the dendritic cell pool are specified.

skin and lung CD14 ${ }^{+}$DC recently were demonstrated to be most closely related to blood monocytes and tissue macrophages (12, 13), which questions their DC origin.

\section{DEVELOPMENT}

In mice, the macrophage and DC progenitor (MDP) gives rise to monocytes and the common DC progenitor (CDP). The latter has lost the potential to generate monocytes and macrophages [reviewed by Ref. $(14,15)]$. Recent fate-mapping and cellular barcoding studies have confirmed $\mathrm{CDC}$ as an independent hematopoietic lineage $(16,17)$. In the bone marrow, CDP give rise to pre-DC that migrate via the blood into LN and NLT, and terminally differentiate into LN and NLT cDC subsets. Once in the periphery, DC have a short life-span and retain a high degree of plasticity that enables a rapid and diverse response to specific extrinsic stimuli.

Human DC arise from BM precursors and it has recently been shown that both granulocyte-macrophage progenitors (GMP) and multi-lymphoid progenitors (MLP) can generate DC in vitro or following adoptive transfer experiments in mice (18). Consistent with this, in vivo data on human DC deficiency caused by a GATA2 mutation demonstrate that a complete absence of MLP (and only reduced numbers of GMP) results in loss of all DC (19). It is unknown however, whether committed DC progenitors exist in humans. So far, equivalents of mouse MDP, CDP, and pre-DC have not been found. Identification of early DC precursors in human blood is complicated by the fact that, in contrast to mouse DC precursors, human $\mathrm{CD} 34^{+}$hematopoietic stem cells already express MHC class II. It has been speculated that human circulating $\mathrm{CDC}$ may be regarded as pre-DC that undergo their final DC differentiation stage in situ $(4,10,13)$. CD1c ${ }^{+}$and $\mathrm{CD} 141^{+} \mathrm{cDC}$ proliferate more in the blood than in the $\operatorname{LN}(10,20)$, suggesting that in the blood they are not fully differentiated. In contrast to $\mathrm{cDC}$, both blood and LN-derived pDC do not proliferate (10,20), supporting the idea that pDC leave the bone marrow fully differentiated (21).

\section{HUMAN MONONUCLEAR PHAGOCYTE SYSTEM: HOW DC DIFFER FROM MONOCYTES AND MACROPHAGES}

The human mononuclear phagocyte system has historically been divided into macrophages, monocytes, and DC, with classification mainly based on phenotypic, anatomical, and/or functional criteria. In this classification, DC are distinguished from monocytes and macrophages amongst others by their dendrite morphology, high levels of MHC class II expression, and superior migratory and naïve T-cell priming properties. Transcriptional profiling studies have confirmed that quiescent primary $\mathrm{CD}_{1} \mathrm{c}^{+} \mathrm{cDC}$, $\mathrm{CD} 141^{+} \mathrm{cDC}$, and pDC cluster together and form distinct populations separate from monocytes and macrophages (8). However, recent studies have also revealed cases of "mistaken identity" and have challenged several long-standing paradigms regarding the ontogeny and (functional) classification of APC. Especially during inflammation or infection, classifying APC subsets is complicated.

\section{MONOCYTES}

Monocytes are the most prominent mononuclear phagocyte of the blood compartment and display a wide array of scavenger and pattern recognition receptors that enables them to rapidly respond to danger signals and pathogen encounter. The classical view is that monocytes circulate in the blood for a few days before migrating into tissues where they can develop into macrophages or DC. Renewed interest in recent years has revealed that monocytes may not just be simple transitional and reactive cells but, like DC, display functional diversity and play a critical role in pathogen defense and driving inflammatory diseases.

Human blood monocytes can be distinguished from DC by the expression of CD14, although surface expression levels can vary. It is important to note that while CD11c is a specific DC marker in mice, $>95 \%$ of human monocytes also express CD11c. Three different types of monocytes have been described based on the expression of CD14 and CD16 (Fc $\gamma$ RIII) and classified by expression profiling and hierarchical clustering $(4,22)$ : (1) classical CD14 ${ }^{++} \mathrm{CD}_{16}{ }^{-},(2)$ intermediate $\mathrm{CD} 14^{++} \mathrm{CD} 16^{+}$, and (3) non-classical CD14 ${ }^{+} \mathrm{CD} 16^{++}$monocytes (Figure 1). A disparity with DC subsets is that monocyte subsets seem to merely represent subsequent developmental stages; although there is no real evidence it is believed that monocytes leave the bone marrow as $\mathrm{CD} 14^{++} \mathrm{CD} 16^{-}$and can develop via intermediate $\mathrm{CD} 14^{++} \mathrm{CD} 16^{+}$into non-classical $\mathrm{CD} 14^{+} \mathrm{CD} 16^{++}$monocytes (22). Classical CD14 ${ }^{++} \mathrm{CD}_{16}{ }^{-}$monocytes are most prevalent in 
the blood (about $85 \%$ of all monocytes) and are rapidly recruited to tissues in inflammatory responses. CD16-expressing monocytes in general display an advanced stage of differentiation with DC and macrophage-like characteristics and effector functions related to antigen processing and presentation. Numbers of blood CD16 ${ }^{+}$ monocytes rise in inflammatory conditions and they represent the main producers of inflammatory cytokines such as TNF $\alpha$. Especially, the intermediate subtype appears to be highly proinflammatory and has the highest capacity to stimulate (antigenindependent) $\mathrm{T}$-cell responses $(22,23)$. The $\mathrm{CD} 14^{\mathrm{dim}} \mathrm{CD} 16^{++}$ intermediate monocytes can be further subdivided into 6-sulfo LacNAc-positive (slan) and -negative monocytes that both produce high levels of IL-12, TNF $\alpha$, and IL-1 $\beta$. The expression of slan was initially identified on an inflammatory human DC subset, the so-called slan DC (24). These cells were found both in blood and skin tissue $(24,25)$. However, recent data show that slan DC cluster together with, and are indistinguishable from, blood CD16 ${ }^{+}$ monocytes $(13,23)$. This example reveals the difficulties in categorizing APC subsets and even lineages based on surface marker expression and functional characteristics. As will also be discussed further on, CD14 ${ }^{+}$NLT APC, originally classified as DC, may actually represent classical monocytes that have extravasated during steady-state. In line with this, it has been recently challenged whether monocytes become tissue macrophages or DC by default when they exit the bloodstream. Jakubzick and colleagues demonstrated that in steady-state, murine classical monocytes extravasate continuously and carry tissue-derived antigens to the LN without differentiating into macrophages or DC (26). Although monocytes express high levels of MHC class II and also have been shown to be able to retain captured antigen and present antigen-derived peptides, they are relatively poor antigen presenters $(21,23)$. Alternative mechanisms such as cytokine production or antigen sharing with DC may however contribute to supporting adaptive immunity.

Together, recent data point to a model in which under homeostatic conditions monocytes may not represent "simple" converting cells but play a specific and complementary role to DC in tissue surveillance and promoting adaptive immunity. For full differentiation into tissue macrophages or DC, additional triggers may be required. As will be discussed further on (functional) relationships between monocytes and DC/macrophages are completely different during inflammation.

\section{MACROPHAGES}

Macrophages consist of two types: tissue-resident and infiltrating macrophages. Tissue-resident macrophages are, as opposed to DC and monocytes, long-lived non-migratory cells that are specialized in taking up and processing dead cells and debris. They possess high proteolytic activity and are poor antigen presenters. They play an essential role in maintaining tissue homeostasis by clearing cell debris and promote resolution of inflammation and wound healing (27). However, they can also promote inflammation by the production of chemokines like CCL2, CXCL1, and MIF, and cytokines like IL- 6 and TNF $\alpha$, attracting and activating other immune cells $(28,29)$.

Tissue macrophages are highly heterogeneous, a consequence of their tissue-specific niches, but functional specialization in situ is difficult to establish. The origin of tissue-resident macrophages has long been controversial: are they monocyte-derived or selfmaintaining? Recent studies in mice show that under steady-state conditions most tissue macrophages are present from birth and are self-maintaining, independently from monocytes (30-33). As an exception, intestinal macrophages have been shown to be constantly replaced by blood monocytes that in healthy tissue conditions acquire a regulatory expression profile (34). Consistent with the findings of independency from monocytes in mice, several human primary immune deficiencies are associated with severe monocytopenia (35-37) and loss of circulating and tissue DC $(35,36)$ while tissue macrophages are relatively unaffected. Whether tissue macrophages in humans are completely selfrenewing remains to be established since tissue macrophages do not appear to proliferate in situ in steady-state (38) and older data also show involvement of BM-derived cells in the replenishment of tissue macrophages following stem cell transplantation (39).

The second type of macrophages, the infiltrating macrophages, is recruited to tissues in inflammatory conditions. In mice, inflammatory monocytes, resembling human classical monocytes and identified by the expression of Ly6c/GR1 and CCR2, have been found to be the source of infiltrating macrophages; distinction between these and resident macrophages can be based on Ly6c expression since Ly6c expression was mostly stable during the first $24 \mathrm{~h}$ after infiltration while resident macrophages were negative for this marker $(29,40,41)$. In the human setting however, there is still no marker to distinguish infiltrating macrophages from resident macrophages, which makes it hard to study subpopulations. Infiltrating macrophages can be divided into three main populations, with a spectrum of macrophage subpopulations in between, based on function, displaying either a pro-inflammatory profile (originally coined "classically activated" or "M1" macrophages), a regulatory profile, or a wound-healing profile (both originally grouped under the term "alternatively activated" or "M2" macrophages) depending on the tissue context and environmental stimuli $(42,43)$.

\section{FUNCTIONAL SPECIALIZATION HUMAN DC: STEADY-STATE}

Due to technical reasons, DC research in humans is largely restricted to peripheral blood-derived DC, using either ex vivo primary DC or in vitro monocyte-derived DC (Mo-DC). A unique and key feature of DC is their ability to prime naïve T cells. Both $\mathrm{cDC}$ subsets, and to a lesser extent $\mathrm{pDC}$, have been shown to prime $\mathrm{CD}^{+} \mathrm{T}$ cells, this in contrast to freshly isolated blood monocytes. For efficient in vitro $\mathrm{CD} 8^{+} \mathrm{T}$-cell priming all $\mathrm{DC}$ subsets require either TLR stimulation or CD4 ${ }^{+}$T-cell help (20).

\section{PLASMACYTOID DC}

Plasmacytoid refers to the non-dendritic, plasma cell-like morphology of $\mathrm{pDC}$ in their inactivated state. $\mathrm{pDC}$ are characterized by the expression of CD123 (IL-3R), CD303 (BDCA-2), and CD304 (BDCA-4 or Neuropilin-1) and circulate in the blood and LN compartments. Their most notable feature is their ability to quickly secrete large amounts of Type I interferons (IFN) in response to a viral infection (44). pDC selectively express endosomal TLR7 and TLR9 that detect nucleic acids derived from viruses, bacteria, and dead cells. TLR7 or TLR9 ligation triggers a downstream signaling 
cascade resulting in secretion of IFN- $\alpha$, IFN $-\beta$ [reviewed by Ref. (45)], and IFN- $\lambda(46,47)$.

In steady-state, $\mathrm{pDC}$ have a poor capacity to stimulate $\mathrm{CD} 4^{+}$ $\mathrm{T}$ cells due to their low levels of MHC class II and co-stimulatory receptor expression and limited phagocytosis of antigens. Without stimulation pDC seem to be tolerogenic and are implicated in inducing T-cell anergy and promoting regulatory T-cell development $(48,49)$. Following stimulation, pDC acquire a dendritic morphology, upregulate HLA-DR and co-stimulatory molecules, and differentiate into functional APC capable of naïve $\mathrm{CD} 4^{+} \mathrm{T}$-cell activation (45).

\section{CONVENTIONAL DC}

Both $\mathrm{CD} 1 \mathrm{c}^{+}$and $\mathrm{CD} 141^{+} \mathrm{cDC}$ are found in the blood, $\mathrm{LN}$, spleen, and NLT including skin, liver, lung, and gut. $\mathrm{CD} 1 \mathrm{c}^{+} \mathrm{cDC}$ coexpress CD11b and high levels of CD11c whereas CD141 ${ }^{+}$DC express lower levels of CD11c, lack CD11b, and selectively express CLEC9A $(13,50,51)$. The chemokine receptor XCR1 was found to be the most selective marker for both human $\mathrm{CD} 141^{+} \mathrm{DC}$ and mouse $\mathrm{CD} 8 \alpha^{+}$DC when compared to other DC subsets and monocytes $(52,53)$. Additionally, the ligand for XCRI, XCL1, selectively attracts $\mathrm{CD} 141^{+} \mathrm{DC}$ and mouse $\mathrm{CD} 8 \alpha \mathrm{DC}$ in vitro $(52,53)$ and was shown to be required for optimal in vivo priming of CD8 $\mathrm{T}$ cells in mice (52).

The two cDC subtypes differ in TLR expression pattern and responsiveness. Whereas $\mathrm{CD} 1 \mathrm{c}^{+} \mathrm{cDC}$ express all TLR except TLR9, CD $141^{+}$cDC highly express TLR3 and TLR10, have low expression levels of TLR1-2, TLR6, and TLR8, while they lack TLR4-7 and TLR9 $(51,54)$. Stimulation of sorted cDC subsets with TLR ligands confirmed restrictive responsiveness of $\mathrm{CD} 141^{+} \mathrm{cDC}$ and showed differential cytokine/chemokine profiles. $\mathrm{CD}_{141}{ }^{+} \mathrm{cDC}$ were found to predominantly respond to TLR3 ligand (poly I:C) triggering by producing CXCL-10/IP-10, CCL5, and IFN- $\beta$. Poly I:C also induced the selective production of IFN- $\lambda$, a type III IFN with anti-viral properties $(51,54,55)$. Skin-derived CD141 ${ }^{+}$ were shown to secrete high amounts of CXCL-10 and TNF $\alpha$ upon TLR3 triggering (13). CD1 ${ }^{+} \mathrm{cDC}$ display a broader repertoire of secreted proteins including IL-1 $\beta$, IL-12, IL-6, TNF $\alpha$, CXCL8/IL8, CCL3, CCL4, and CCL5 and CXCL-10 upon TLR3 stimulation $(51,54)$. Selective high production of IL-12 by CD1c ${ }^{+}$DC was confirmed upon stimulation with a combination of TLR ligands (20), although use of a different cocktail, of poly I:C plus cytokines, showed that CD141+ DC, too, are well able to produce IL-12p70 (51). Most likely available environmental stimuli will determine local production of this and other cytokines by specific cell subsets.

\section{ANTIGEN PRESENTATION}

Primary $\mathrm{CD} 1 \mathrm{c}^{+}$and $\mathrm{CD} 141^{+}$have a similar capacity to take up fluorescent protein and they were shown to process and present recombinant protein to autologous $\mathrm{CD}^{+} \mathrm{T}$ cells with similar efficiency (51). In addition, they express similar levels of MHC class I and are equally efficient in peptide antigen presentation to autologous $\mathrm{CD}^{+} \mathrm{T}$ cells (51). Antigen processing and presentation requires limited degradation of proteins and preservation of cognate T-cell epitopes. Similar to mouse DC, ex vivo human pDC and $\mathrm{CDC}$ have been shown to contain low proteolytic activity (56). In contrast, Mo-DC show high protein degradation capacity, comparable to that of macrophages (56). With maturation, lysosomal $\mathrm{pH}$ drops and degradation capacity increases, which may explain the increased degradation of proteins found in Mo-DC.

\section{T-CELL POLARIZATION}

Antigen-presenting cells and their secreted products are believed to be decisive in naïve T-cell differentiation and $\mathrm{CD} 4^{+} \mathrm{T}_{\mathrm{H}}$-cell subset polarization. Accordingly, $\mathrm{CD} 4^{+} \mathrm{T}$-cell differentiation was found to be defective in a patient with IRF8 autosomal recessive deficiency, characterized by the lack of monocytes and DC. Whereas ex vivo $\mathrm{CD} 4^{+} \mathrm{T}$-cell proliferation was within normal range, production of IFN- $\gamma$, IL-17, and to a lesser extent IL-10, was largely reduced in response to $\mathrm{CD} 3 / \mathrm{CD} 28$ or PMA/ionomycin (36).

In an allogeneic MLR both CDC subsets are equally strong stimulators of $\mathrm{CD}^{+} \mathrm{T}$ cells regardless of their activation status (51), however T-cell polarization capacities may differ based on the differential TLR and cytokine/chemokine expression profiles. High expression of TLR3 by CD141 ${ }^{+} \mathrm{DC}$ and their capacity to produce high amounts of IFN- $\beta$, CXCL-10, and IL-12p70 all point to $\mathrm{T}_{\mathrm{H}} 1$-inducing function. Indeed, unstimulated $\mathrm{CD} 141^{+}$ and $\mathrm{CD} 1 \mathrm{c}^{+} \mathrm{cDC}$ were found to induce $\mathrm{T}_{\mathrm{H}} 1$ differentiation from naïve CD4 T cells, with TLR stimulation further promoting this capacity $(51,54)$. The highest percentage of IFN- $\gamma$-producing cells was observed following TLR3 triggering of CD141 ${ }^{+} \mathrm{CDC}(54)$. Both unstimulated and poly I:C-stimulated $\mathrm{CDC}$ subsets did not induce IL-4, IL-5, and IL-10 production in an allogeneic MLR (51) and, in general, blood $\mathrm{DC}$ fail to induce efficient $\mathrm{T}_{\mathrm{H}} 2$ polarization (10). In contrast, $\mathrm{LN}$-resident $\mathrm{CDC}$ subsets induce both $\mathrm{T}_{\mathrm{H}} 1$ and $\mathrm{T}_{\mathrm{H}} 2$ cytokine production in naive allogeneic $\mathrm{T}$ lymphocytes (10) and skin resident Langerhans cells (LC) have been shown to preferentially induce differentiation of $\mathrm{T}_{\mathrm{H}} 2$ cells (57).

Schlitzer and colleagues have assessed $\mathrm{T}_{\mathrm{H}} 17$ induction by human DC subsets from peripheral blood and lung tissue. Unstimulated lung CD1c ${ }^{+}$DC were found to express levels of IL-23p19 mRNA higher than those expressed by CD $141^{+}$DC but comparable to those expressed by CD14 $4^{+} \mathrm{DC} /$ monocytes (12). Consistent with this, both lung and blood $\mathrm{CD} 1 \mathrm{c}^{+} \mathrm{DC}$ more potently induced IL-17 production by autologous $\mathrm{CD} 4^{+} \mathrm{T}$ cells than $\mathrm{CD} 141^{+} \mathrm{DC}$ and $\mathrm{CD} 14^{+} \mathrm{DC} /$ monocytes. Unstimulated $\mathrm{CD} 141^{+}$from the liver were however reported to induce both IL- 17 and IFN- $\gamma$ production by allogeneic $\mathrm{T}$ cells (58).

\section{CROSS-PRESENTATION}

Cross-presentation is the presentation of acquired exogenous antigens on MHC class I molecules and is essential for the initiation of $\mathrm{CD}^{+} \mathrm{T}$-cell responses $(59,60)$. In mice, steady-state $\mathrm{LN}$ $\mathrm{CD} 8 \alpha$ DC seem to be the most efficient at cross-presentation (60-62). When $\mathrm{CD} 141^{+} \mathrm{cDC}$ were identified as mouse CD8 $\alpha^{+}$ homologs (8) numerous groups subsequently described superior cross-presenting ability of blood CD $141^{+} \mathrm{cDC}(50-53)$. Whereas one study showed superior cross-presentation of unstimulated $\mathrm{CD}_{141}{ }^{+} \mathrm{cDC}$ compared to $\mathrm{CD} 1 \mathrm{c}^{+} \mathrm{cDC}$ and $\mathrm{pDC}(53)$, other groups reported that unstimulated $\mathrm{CD} 141^{+} \mathrm{cDC}$ were unable to cross-present $(6,20,51)$. Recent studies have revealed that, with the proper stimuli, all human DC subsets are able to cross-present in vitro (63). However, $\mathrm{CD} 141^{+} \mathrm{cDC}$ were shown to be the most efficient cross-presenting subset following poly I:C stimulation 
(20, 51, 52), when using necrotic cell-associated antigens (51, 53), antigen delivered by Fc $\gamma$ receptor targeting (64), or antigen delivered to late endosomes/lysosomes (65). The superior ability in cross-presenting necrotic cell-derived antigens may be explained by the selective expression of Clec9A on CD $141^{+} \mathrm{cDC}$ (as well as on CD8 $\alpha^{+}$mouse DC), a dead cell receptor that favors cross-presentation through cargo delivery to both MHC class I and II (51).

In vivo cross-presentation occurs in secondary lymphoid organs and the Amigorena group has demonstrated that freshly isolated tonsil-resident $\mathrm{LN} \mathrm{CD} 1 \mathrm{c}^{+} \mathrm{cDC}_{\mathrm{CD}} \mathrm{C} 41^{+} \mathrm{cDC}$, and $\mathrm{pDC}$ all display equal intrinsic cross-presenting capacity (66). In addition, ex vivo unstimulated skin-derived LC and $\mathrm{CD} 141^{+}$cells potently cross-present $(13,57)$. It has therefore been suggested that blood DC may not be fully functional yet and only acquire efficient cross-presenting capabilities after a final step of differentiation in lymphoid organs and tissues (66).

Taken together these data demonstrate that although $\mathrm{CD} 141^{+}$ have characteristics of specialized cross-presenters compared to other DC subsets, this is highly affected by activation status, location, type of antigen, and inflammatory signals (63). It is also important to note that the requirements for DC subsets to efficiently cross-present may be different than those to stimulate $\mathrm{CD}^{+}$memory $\mathrm{T}$ cells/T-cell clones versus priming of naïve $\mathrm{CD} 8^{+}$ T cells.

FUNCTIONAL SPECIALIZATION HUMAN DC: INFLAMMATION In an inflammatory setting, monocytes/DC change their phenotype thereby complicating the distinction between phenotypic plasticity within a monocyte/DC population versus discrete subsets. For example, APC can upregulate phenotypic "markers" such as CD14, CD11b, CD141, and CD16, which are used in steadystate to define lineages or functional subsets. Another complicating factor is tissue-instructed differentiation, which confounds hierarchical clustering and principle component analyses. When CD1c and CD141 peripheral blood and tonsilar tissue DC were used for transcriptional profiling and hierarchical clustering, transcriptional activity was more pronounced in tonsil DC and with more transcriptional overlap between the subsets compared to the blood-derived counterparts (7). It was suggested that this is most likely the effect of inflammatory maturation stimuli present in the tonsilar tissue (7) and in general most tissue-specific effects may be due to the induction of different states of maturation. Both mouse and human DC have indeed been shown to undergo profound genetic reprograming in vivo during their maturation (67). Interestingly, genes that were identified to be regulated upon DC maturation were irrespective of stimuli, species, or DC subsets. In addition, following an in vivo virus challenge mouse DC subsets underwent similar extensive reprograming in their gene expression pattern but maintained their own subset profile, suggesting a common and conserved maturation program without loss of identity (67).

Along with phenotypical changes, functional changes occur following maturation. In general, microbial encounter or inflammatory stimuli change the main function of DC from phagocytosis into efficient priming of T cells. After a transient increase in antigen-uptake, changes in endosomal trafficking and antigen processing lead to increased presentation and, along with upregulation of co-stimulatory molecules, this results in efficient T-cell stimulation. One example of a functional change is the observation that all blood DC can cross-present after stimulation with TLR agonist, while in steady-state the capacity to cross-present is limited $(10,51,52)$.

\section{INFLAMMATORY DENDRITIC CELLS: THE RELATIONSHIP BETWEEN MONOCYTES AND DENDRITIC CELLS IN INFLAMMATORY CONDITIONS}

One of the important outstanding questions in DC biology is the (functional) relationship between DC and monocytes in inflammatory conditions. Monocytes have long been known to be able to differentiate into DC when properly stimulated in vitro $(68,69)$. The best-studied human DC are in fact in vitro-generated Mo-DC since they can be generated in large numbers (69). Genomewide expression profiling has demonstrated that human GM-CSF Mo-DC have more similarities with monocytes than with blood DC subsets (8). Therefore, GM-CSF Mo-DC may share a number of developmental, phenotypic, and functional characteristics with so-called "inflammatory" DC (infDC) - DC derived from monocytes in an inflammatory setting. However, in humans it has never been demonstrated that monocytes give rise to DC in situ. In mice, the in vivo role of Mo-DC have also long been elusive until in 2003, two studies showed in vivo differentiation of monocytes into the above mentioned infDC $(70,71)$. These infDC were shown to be recruited to the site of inflammation, producing large amounts of $\mathrm{TNF} \alpha$ and iNOS (therefore, they were also referred to as TNF-iNOS producing "Tip" DC) and were found to be crucial in pathogen clearance (71). Later, it was demonstrated that infDC are also essential in promoting early pathogen-specific T-cell responses (72), although it has not yet been formally demonstrated whether they are involved in in vivo T-cell priming. infDC seem to be specifically important in stimulating $\mathrm{T}$-cell polarization and cytokine production (73). In mice, infDC preferentially induce $\mathrm{T}_{\mathrm{H}}$ 1-type responses, but $\mathrm{T}_{\mathrm{H}} 2$ or $\mathrm{T}_{\mathrm{H}} 17$ type responses have also been reported [reviewed by Ref. $(73,74)$ ] depending on the type of (inflammatory) environment. Taken together, monocyte-derived infDC play an important role in the initiation of inflammation and with their rapid and numerous recruitment to inflamed/infected sites and high production of inflammatory cytokines they may act as safeguards that support the function of cDC. Additionally, their highly plastic and versatile nature enables them to respond to local cues and acquire specific activities.

Identifying the in vivo human counterpart of infDC has proven to be a challenge. As discussed further on, several infDC phenotypes have been described that are present only in inflamed skin, including Tip-DC and inflammatory dendritic epidermal cells (IDEC). Although all these DC subsets can be considered infDC, their origins and mutual relationship are currently unclear. In the duodenal mucosa of celiac disease patients, there is a rapid accumulation following a gluten challenge of inflammatory $\mathrm{CD} 11 \mathrm{c}^{+} \mathrm{CD} 14^{+} \mathrm{CD} 163^{+} \mathrm{CCR} 2^{+} \mathrm{DC}$, which are suggested to be monocyte-derived due to their phenotypic overlap with classical blood monocytes (75). In the lungs of mice, upon inflammatory conditions like respiratory viral infections, an influx of activated inflammatory CD11b and Ly6c-expressing DC is found, together with IFN-producing killer DC that are CD11 $c^{\text {dim }}$ and B220 ${ }^{+}$as 
reviewed in Ref. (76)]. These lung-infiltrating $\mathrm{CD}_{11 \mathrm{~b}}{ }^{+} \mathrm{Mo-DC}$ were shown to be important in the production of chemokines during allergic inflammation and were capable of inducing $\mathrm{T}_{\mathrm{H}} 2$ cell immunity (74). Additionally, in viral-induced pulmonary inflammation, $\mathrm{CD} 11 \mathrm{~b}^{+}$Mo-DC induce strong naïve T-cell proliferation and produce NO synthase 2 (NOS2), playing a predominant role in pathology (77). However, again, how this translates to the human setting remains to be investigated. Another very recent paper describes a specific subset of DC, present in synovial fluid (SF) of RA patients and in inflammatory tumor ascites, that shares molecular features with both conventional CD $1 \mathrm{c}^{+} \mathrm{DC}$ and monocytes/macrophages (78). These CD1c ${ }^{+}$infDC co-express CD14, CD206, and CD11b, and are enriched for a Mo-DC signature. Although these data indicate a close relationship with monocytes, also here it remains to be established whether they are derived from monocytes or merely represent activated $\mathrm{CD}_{1} \mathrm{c}^{+} \mathrm{DC}$. In terms of function, $\mathrm{CD} 1 \mathrm{c}^{+}$exudate-derived infDC were demonstrated to promote IFN- $\gamma$ and IL-17A production by autologous memory $\mathrm{T}$ cells and induce IL-17A production by naïve allogeneic T cells and (78) by the production of TGF- $\beta$, IL- $1 \beta$, IL- 6 , and IL23 , stressing their pro-inflammatory nature. Although exudates are only a partial reflection of what is going on in the inflamed tissues, the highly inflammatory environment and presence of large cell numbers provide an excellent tool to study APC biology and interaction with activated $\mathrm{T}$ cells under inflammatory conditions. We have demonstrated that in SF of juvenile idiopathic arthritis patients $\mathrm{T}$ cells become resistant to Treg-mediated suppression and that impaired T-cell regulation can be specifically induced by the APC-derived pro-inflammatory cytokines IL- 6 and TNF $\alpha(79,80)$.

\section{HUMAN DC IN CHRONIC AUTOIMMUNE INFLAMMATION}

Substantial support is available for the pathogenic role of DC in multiple autoimmune diseases by driving activation and differentiation of effector T-cell populations (81). However, the specific functional roles of DC subsets, as opposed to the general population of DC remains to be established and is one of the future key questions. The best example of the involvement of a specific DC subset in human autoimmune disease so far is the pDC driven type I IFN pathogenesis proposed in several systemic autoimmune diseases. Whereas pDC are largely absent from tissues in steadystate they can accumulate during inflammation. As pDC are not only able to sense viral nucleic acids but also self-nucleic acids in injured tissue leading to their activation and type I IFN production. Tissue infiltration of activated $\mathrm{pDC}$ has been reported in skin lesions of SLE, psoriasis, and systemic sclerosis patients $(82,83)$, salivary glands of Sjögren's disease patients (84), and muscles and skin of juvenile dermatomyositis patients (85). In these autoimmune diseases, pDC are the major source of type I IFN and are implicated in the initiation of inflammation and the transition to a chronic disease (81).

Migratory tissue DC play a central role in the induction of inflammation. Due to relatively easy accessibility, most human tissue DC work has been performed on skin tissue-derived DC. Therefore, in the next part we will discuss in more detail the function of DC subsets in healthy and (chronically) inflamed skin as a model for human tissue DC biology.

\section{SKIN DC: STEADY-STATE}

The skin hosts several distinct DC subsets within its two compartments and the classical categorization consists of LC, residing in the epidermis, and $\mathrm{CD} 1 \mathrm{a}^{+} \mathrm{CD} 14^{-}$and $\mathrm{CD} 14^{+} \mathrm{DC}$, residing in the dermis $(86,87)$ (for an overview of skin DC in steady-state see Figure 2).

\section{LANGERHANS CELLS}

Langerhans cells, due to their location in the epidermis and their protruding dendrites, are a typical example of a DC sentinel, surveying the epidermis for foreign antigens. With their continuous migration to draining LN, they constitute the first immunological barrier of the skin. In human, LC can be identified based on the expression of CD11c, CD32, CD45, FceR1, high levels of CD1a, CD207/langerin, CD324/E-cadherin, CD326/EpCAM, and HLA-DR, and specific expression of Birbeck granules $(88,89)$. In steady-state, LC are continuously replaced from a resident precursor pool (90), whereas in inflammation LC are repopulated by blood precursors (91).

In vitro human LC are able to take up antigens, process them efficiently and present them to T cells to induce activation, proliferation, and cytokine production (57). They are able to initiate $\mathrm{T}_{\mathrm{H}} 1$, $\mathrm{T}_{\mathrm{H}} 2, \mathrm{~T}_{\mathrm{H}} 17$, and $\mathrm{T}_{\mathrm{H}} 22$ responses (92). LC migrate to skin-draining lymph nodes in steady-state $(10,93)$, and LN-derived LC have been found to preferentially induce $\mathrm{T}_{\mathrm{H}} 2$ polarization in vitro (10). Additionally, LC are rather efficient at cross-presenting exogenous antigen to naïve $\mathrm{CD}^{+} \mathrm{T}$ cells $(57,94)$.

\section{DERMAL DC}

In human dermis, during steady-state conditions, DC are classically divided into $\mathrm{CD}_{1}{ }^{+}$and $\mathrm{CD} 1 \mathrm{a}^{+} \mathrm{DC}(86) . \mathrm{CD}^{+} 4^{+}$dermal dendritic cells (DDC) show variable expression of CD1a, CD1c, and CD163 (38). Dermal resident macrophages also express CD14 but they can be distinguished from DDC by the lack of CD1c and the presence of high levels of CD163 and FXIIIa and high auto-fluorescence $(38,95)$. Nevertheless, CD14 ${ }^{+}$DDC express a

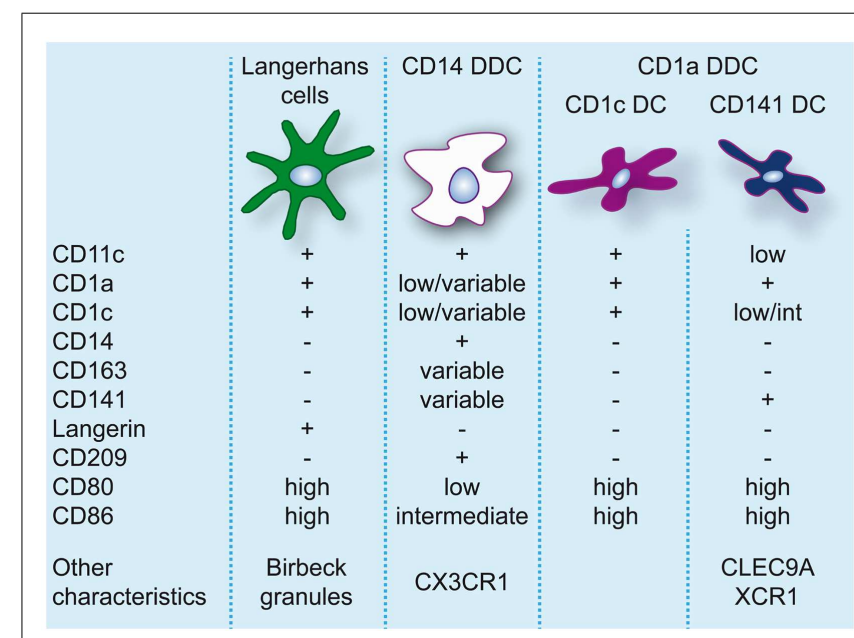

FIGURE 2 | Dendritic cell populations in human skin during steady-state conditions. Expression levels of markers commonly used to identify and discern these populations are indicated. 
prominent "mixed" DC/macrophage phenotype and comparative transcriptomic analysis has recently demonstrated the close relation of CD14 ${ }^{+}$DDC with blood monocytes $(13,96)$, suggesting a monocyte origin. These cells should not be confused with MoDC or infDC that only appear during inflammation and display an activated and pro-inflammatory phenotype. CD14 ${ }^{+}$DDC in contrast express low levels of CD80 and CD86 and are relatively poor inducers of naïve T-cell proliferation $(38,57,95,97,98)$. They do however efficiently take up antigen, possibly due to expression of c-type lectins like CD206 and CD209/DC-SIGN $(95,99)$. They also have the ability to induce Treg through high production of IL-10 (100).

Skin-derived $\mathrm{CD} 1 \mathrm{a}^{+} \mathrm{DC}$ express high levels of CD80 and CD86 and strongly induce allogeneic naïve $\mathrm{CD} 4^{+} \mathrm{T}$ cells and $\mathrm{CD} 8^{+} \mathrm{T}$ cell proliferation $(38,57,95,97,98)$. CD1a ${ }^{+}$DDC isolated from skin-draining lymph nodes were found to preferentially induce $\mathrm{T}_{\mathrm{H}} 2$ polarization similar to LC (10). However, human CD1a ${ }^{+}$ DDC seem to be more heterogeneous than originally thought. The majority of $\mathrm{CD} 1 \mathrm{a}^{+} \mathrm{DDC}$ are uniformly $\mathrm{CD} 1 \mathrm{c}^{\text {high }}$, but recently $\mathrm{CD} 1 \mathrm{c}^{\text {lo }} \mathrm{DDC}$ highly positive for CD141 were isolated from skin explants. These DC resembled the phenotype of blood CD141+ DC, expressing high levels of XCR1, TLR3, CLEC9A, CADM1, and FLT3, and were found to be superior to CD1c $\mathrm{c}^{+} \mathrm{DDC}, \mathrm{CD} 14^{+}$ DDC, and LC at cross-presenting soluble antigen (13). In contrast to blood $\mathrm{CD}_{141^{+}} \mathrm{DC}$ cross-presentation by $\mathrm{CD} 141^{+} \mathrm{DDC}$ was even induced in the absence of TLR3 stimulation, which underscores their activated phenotype. Variable expression of CD141 on CD14 ${ }^{+}$DDC has also been reported $(13,100)$. However, these cells lack the critical features of cross-presenting DC (13) and induce Treg via the production of IL-10 (100).

\section{SKIN DC: INFLAMMATION}

Inflammatory diseases of the skin have been associated with altered DC numbers, suggesting a role of DC in these pathologies. However, what role DC play is often still unclear and remains to be resolved. In both atopic dermatitis $(\mathrm{AD})$ and psoriasis, the two most common inflammatory skin diseases, DC numbers are increased (for an overview see Figure 3). To elucidate the role that DC can play in skin inflammation and inflammation in general,

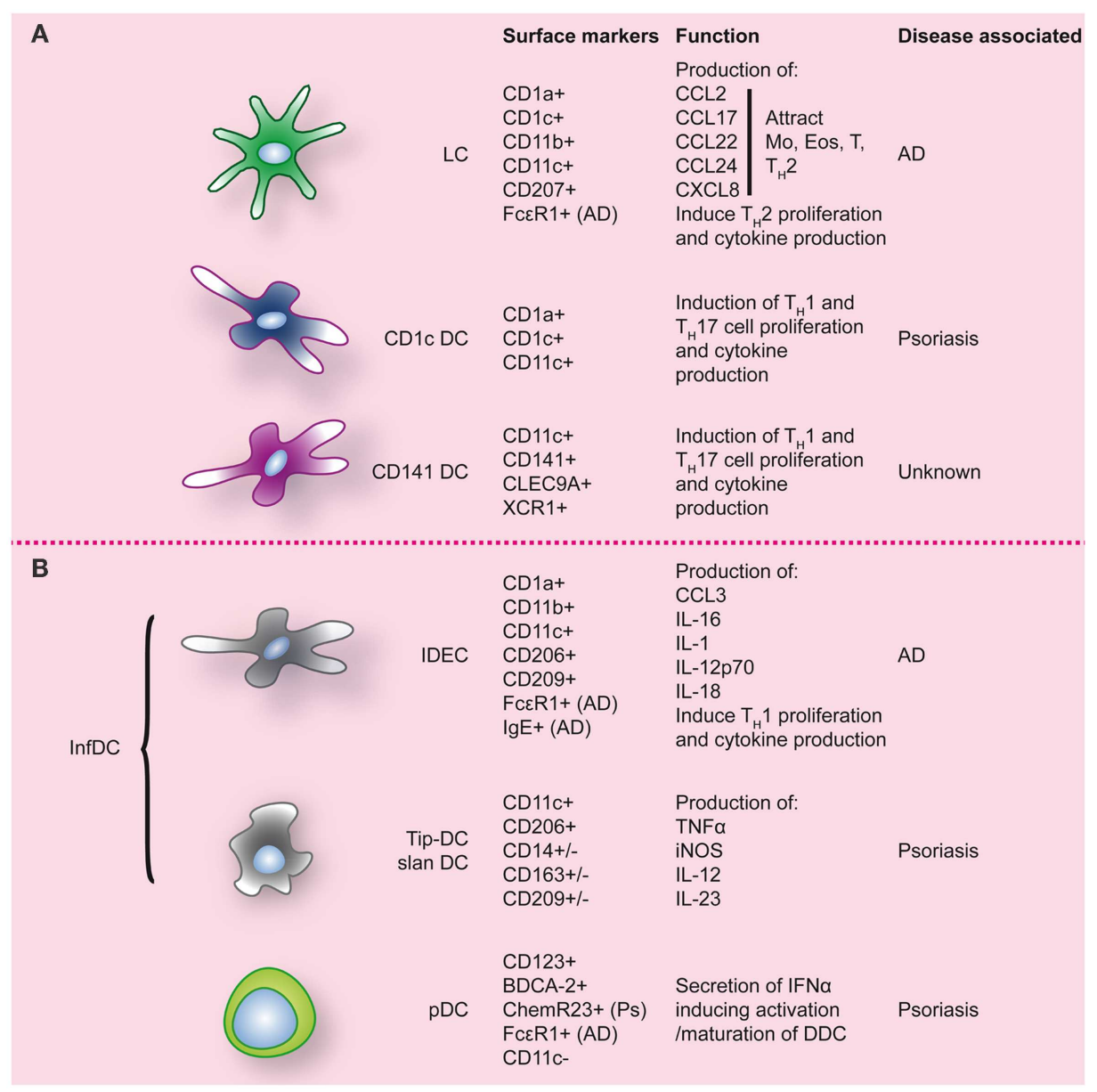

FIGURE 3 | Dendritic cell populations in human skin during inflammatory conditions. Inflamed skin contains not only DC that were already present at steady-state (A), but also DC that migrated into the skin (B). Markers commonly used to identify these DC populations are indicated, as well as markers/function associated with specific inflammatory conditions of the skin. LC, Langerhans cell; Ps, psoriasis; AD, atopic dermatitis. 
we will draw examples from psoriasis and $\mathrm{AD}$, each with their own $\mathrm{T}_{\mathrm{H}^{-} \text {-cell signatures. }}$

\section{PSORIASIS}

Psoriasis is a common relapsing immune-mediated inflammatory disease affecting skin and joints, typically presenting as welldemarcated, red, and scaly plaques (101). The typical histological features of psoriatic plaques like thickening of the skin, elongation of the epidermis, and increased numbers and dilated dermal blood vessels, are caused by an immune response gone out of control, in which keratinocytes, DC, and T cells all play a role. In psoriatic lesions, CD8+ T cells are mostly found in the epidermis, while pDC, myeloid DDC and $\mathrm{T}_{\mathrm{H}} 1$ and $\mathrm{T}_{\mathrm{H}} 17 \mathrm{CD} 4^{+}$cells, are found in the dermis (102).

\section{Plasmacytoid DC}

In psoriatic lesions, the type I IFN system has been shown to be activated when compared to non-involved skin of the same patient or healthy control (HC) skin (103). Activated pDC are found in increased numbers not only in lesional psoriatic skin $(104,105)$, but also in uninvolved skin of psoriatic patients, compared to normal skin from HC (104). IFN- $\alpha$ signaling, but not IFN- $\alpha$ expression, is upregulated only in lesional psoriatic skin. Following exposure to light, a well-established treatment for psoriasis, $\mathrm{pDC}$ numbers and IFN- $\alpha$ signaling are rapidly reduced in lesional skin, in parallel with a clinical improvement (106). The underlying mechanism of $\mathrm{pDC}$ activation in psoriatic skin seems to be via the cathelicidin LL37, an antimicrobial peptide that is produced by keratinocytes and neutrophils and is overexpressed in psoriatic skin. This peptide binds self-DNA/RNA fragments that are released from stressed or dying skin cells, and subsequently triggers TLR7/9 on pDC to induce activation and production of type I IFN $(107,108)$. Similarly, other proteins secreted by neutrophils via the neutrophil extracellular trap (NET) like HMGB, HNE, CatG, and SLP1, together with DNA induce pDC to produce IFN- $\alpha$, and possibly play a role in early psoriasis (109-111). Indeed, in a case report, triggering of TLR7 via topical treatment with TLR7 ligand imiquimod was shown to induce exacerbation of psoriasis via massive induction of type I IFN signaling (112). Similarly, in some skin-related cancers, in which imiquimod is used as a topical therapy, imiquimod application strongly increased IFN- $\alpha$ signaling that was related to the number of $\mathrm{pDC}$, suggesting that again pDC-derived IFN- $\alpha$ is responsible for this (113).

While in early and developing psoriasis the role of $\mathrm{pDC}$ seems clear, a role in more chronic psoriasis is less distinct. Indeed, when corresponding $\mathrm{pDC}$ to phases of psoriasis, $\mathrm{pDC}$ are especially found in early and developing psoriasis, and hardly in chronic psoriasis. This temporal dichotomy correlates well with chemerin levels, a chemokine that attracts chemR23-expressing $\mathrm{pDC}$ and is highly expressed in pre-psoriatic skin and early lesions $(114,115)$.

\section{Dermal DC}

While pDC are considered to play a vital role in the development of psoriatic lesions, DDC are thought to be of major importance in the more chronic phase of psoriasis. In psoriatic dermis, CD11c $\mathrm{c}^{+} \mathrm{DC}$ are increased up to 10 times compared to non-lesional skin $(98,116,117)$. T cells surrounding the DDC were found to be persistently activated and differentiated toward a type 1 effector phenotype, both cytotoxic and $\mathrm{T}_{\mathrm{H}}$ cells (118, 119). Psoriatic lesion-derived DDC were found to be more potent inducers of spontaneous proliferation of autologous $\mathrm{T}$ cells, especially of the $T_{H} 1$ subtype producing high amounts of IFN- $\gamma$ and IL-2, than DDC from HC skin or CDC from peripheral blood of psoriatic patients $(98,118)$. Others show that psoriatic skin-derived DDC not only induce $\mathrm{T}_{\mathrm{H}} 1$ but also $\mathrm{T}_{\mathrm{H}} 17$ polarization (120). DDC from psoriatic patients are indeed a potent source of IL-23 (117, 121-123) and IL-12, although literature remains in discord on whether or not there is an increase of IL12 expression in psoriatic skin compared to normal skin (122, 124, 125).

Dermal dendritic cells in psoriatic skin can be further subdivided into three subsets: $\mathrm{CD}_{1}{ }^{+} \mathrm{DC}, \mathrm{CD}_{141^{+}} \mathrm{DC}$, and

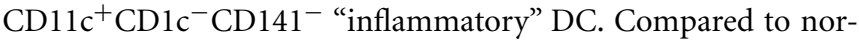
mal skin, $\mathrm{CD}_{1 c^{+}} \mathrm{DC}$ numbers are decreased and $\mathrm{CD} 141^{+} \mathrm{DC}$ increased in both non-lesional and lesional skin of psoriatic patients. However, the increase in infDC [up to 30 times compared to normal skin (120)] is largely responsible for the total increase of $\mathrm{CD}_{11 \mathrm{c}^{+}}$cells in psoriatic lesional skin. Both $\mathrm{CD} 1 \mathrm{c}^{+}$and $\mathrm{CD} 1 \mathrm{c}^{-}$ DDC populations from psoriatic skin are able to induce T-cell proliferation and production of IFN- $\gamma$ and/or IL-17 to the same extent (120).

\section{Inflammatory DC}

"Inflammatory" $\mathrm{CD} 11 \mathrm{c}^{+} \mathrm{CD} 1 \mathrm{c}^{-} \mathrm{CD} 141^{-} \mathrm{DDC}$, expressing high levels of TNF- $\alpha$ and iNOS, specifically accumulate in psoriatic lesions (126). In analogy with the mouse DC subset, they have been termed Tip-DC (126). Dermal Tip-DC express some CD14, CD163, and CD209/DC-SIGN (120) and are assumed to be monocyte-derived. The pathogenic impact of these DC is thought to result from the production of pro-inflammatory cytokines. TNF $\alpha$ induces keratinocytes to express ICAM-1, CXCL8, and also pro-inflammatory cytokines like IL-1 $\beta$ and IL-6 (102). iNOS in inflamed tissues catalyzes the production of nitric oxide (NO) that in inflamed skin can lead to vasodilation of dermal blood vessels in psoriatic skin (102). In addition Tip-DC have been shown to produce high levels of IL-23, a pro-inflammatory cytokine driving Th17 polarization and strongly associated with psoriasis (127, 128). Following effective therapy in psoriasis, TNF $\alpha$, iNOS, and IL23 production by Tip-DC is strongly reduced. A (sub-)population of DC in psoriasis was demonstrated to express 6-SulfoLacNac and display similarities with peripheral "slanDC" (25). The complete transcriptional overlap of blood slanDC with $\mathrm{CD} 16^{+}$monocytes, also suggests a monocyte origin of skin slanDC $(13,23)$. Like pDC, dermal slanDC are reactive to self-RNA-LL37 complexes (25) and their high IL-1 $\beta$, IL-6, TNF $\alpha$, IL-12, and IL-23 production results in $\mathrm{T}_{\mathrm{H}} 1 / \mathrm{T}_{\mathrm{H}} 17 \mathrm{~T}$-cell programing (25). Because of their phenotypic signature, it is likely that dermal Tip-DC and slanDC represent the same infDC population although subpopulations may exist. In conclusion, accumulating dermal infDC seem to play a key role in the progression of psoriasis and sustenance of psoriatic lesions by secreting large amounts of pro-inflammatory mediators including iNOS, IL-12/IL-23, and TNF $\alpha$. The latter cytokines, and especially IL-23, have been proven effective targets for clinical therapy in psoriasis. 


\section{Langerhans cells}

A vital role for LC in psoriasis has not been described thus far. Compared to normal skin, LC frequency and phenotype are normal in uninvolved skin of psoriatic patients. However, mobilization of LC toward lymph nodes in response to allergens or cytokines like $\mathrm{TNF} \alpha$ and IL-1 $\beta$, factors that normally induce migration of these cells, was largely absent (129). Furthermore, culture of psoriatic patient-derived monocytes into LC (mLC) showed migratory capacity similar to those cultured from HCderived monocytes, suggesting that there is no intrinsic DC defect but an underlying altered epidermal microenvironment in psoriasis patients (130). Such local change may not only influence LC function, which can be used to distinguish between early-onset and late-onset psoriasis (131), but perhaps also be the basis for the development of psoriasis.

Together, there seems to be a pivotal role for DC in the pathogenesis of psoriasis, not only during the initiation, but also the sustenance of the disease. However, especially in the non-acute phase of the disease, it remains difficult to determine what the exact role is of each DC subset. Moreover, further definition of these subsets need to be addressed. While CD11c ${ }^{+} \mathrm{CD} \mathrm{c}^{-}$inflammatory DDC were presented as a separate DC subset (71), gene expression profiling of $\mathrm{CD} 11 \mathrm{c}^{+} \mathrm{CD} 1 \mathrm{c}^{+}$and $\mathrm{CD} 11 \mathrm{c}^{+} \mathrm{CD} 1 \mathrm{c}^{-} \mathrm{DDC}$ shows that these two populations are closely related (132), suggesting that the inflammatory DDC are perhaps a more activated

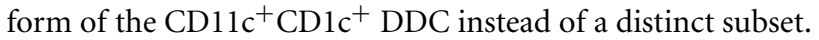

\section{ATOPIC DERMATITIS}

Atopic dermatitis, or atopic eczema, like psoriasis, is a common relapsing inflammatory disease affecting the skin. $\mathrm{AD}$ patients typically present with eczematous patches and plaques, histologically defined by epidermal intercellular edema (spongiosis) and prominent dermal cellular infiltration. In AD skin, T-cell numbers are increased, consisting of mostly $\mathrm{T}_{\mathrm{H}} 2$ cells in the acute phase while there is a prominent $\mathrm{T}_{\mathrm{H}} 1$ aspect in the subacute chronic phase (133-135). Additionally, like in psoriasis, skin DC numbers are increased in general, particularly DC expressing CD11c ${ }^{+}$and $\mathrm{CDla}^{+}(136)$.

\section{Plasmacytoid dendritic cells}

In contrast to psoriasis, there seems to be no role for $\mathrm{pDC}$ in $\mathrm{AD}$ pathogenesis, since they are virtually absent from $\mathrm{AD}$ lesions like in healthy skin (105). However, peripheral pDC in AD carry the FceRI that, when activated induces IL-10 production, while IFN- $\alpha$ production is dramatically decreased compared to that by $\mathrm{pDC}$ from HC (137). Together, this may explain the increased susceptibility of $\mathrm{AD}$ patients to viral infections.

\section{Langerhans cells and inflammatory epidermal dendritic cells}

Two subsets of FceRI-bearing DC are most important in AD. Firstly, LC that show a slightly changed phenotype compared to steady-state (89). Additionally, infiltrating IDEC are present (89). Since the majority of these cells are found in the dermis of AD (136), they are also referred to as myeloid inflammatory dendritic cells (MIDC).

Both LC and IDEC express high levels of FceRI $(89,138,139)$. The expression of this Fc\&RI, in combination with a low expression of $\mathrm{CD} 32 / \mathrm{FC} \gamma \mathrm{RII}$, strongly distinguishes $\mathrm{AD}$ patients from patients with other lesional skin conditions like psoriasis and allergic dermatitis (140). During the acute phase of AD, in which lesions are characterized by a $\mathrm{T}_{\mathrm{H}} 2$ signature, LC may capture antigens via FceRI-bound IgE and become activated, leading to secretion of CCL2/MCP-1 and IL-16, and possibly CXCL8 (141). This induced attraction of monocytes, eosinophils, and T cells. Additionally, LC can internalize, process, and present IgE-associated allergens to $\mathrm{T}$ cells, which can take place locally or in skin-draining $\mathrm{LN}$, resulting in a polarization toward $\mathrm{T}_{\mathrm{H}} 2$ cells and production of $\mathrm{T}_{\mathrm{H}} 2$ cytokines like IL-4, IL-5, IL-13 (141). LC also express high levels of the receptor for TSLP, a ligand that is secreted in ample amounts by keratinocytes. Binding TSLP leads to LC maturation, survival, and secretion of CXCL8, CCL17, CCL22, CCL24, and IL15 , driving $\mathrm{T}_{\mathrm{H}} 2$ recruitment. TSLP-induced $\mathrm{LC}$ activate $\mathrm{T}_{\mathrm{H}} 2$ cells, thereby enhancing the $\mathrm{T}_{\mathrm{H}} 2$ profile in $\mathrm{AD}(141,142)$.

In the subacute and chronic phase of $\mathrm{AD}$, lesions are more characterized by a $\mathrm{T}_{\mathrm{H}} 1$ signature. After migration into the skin monocytes are thought to differentiate into IDEC, the DC subtype that seems to be responsible for the chronic maintenance phase of AD. Phenotypical analysis shows that IDEC are CD1a ${ }^{+}, \mathrm{CD}_{1} \mathrm{~b}^{\mathrm{dim}}$, $\mathrm{CD} 1 c^{\text {dim }}, \mathrm{CD} 11 b^{\text {bright }}, \mathrm{CD} 11 \mathrm{c}^{+}, \mathrm{CD} 23^{\text {dim }} \mathrm{CD} 32^{\text {dim }}, \mathrm{CD} 36^{\text {bright }}$, $\mathrm{CD}^{206^{\text {bright }}} \mathrm{CD}^{\mathrm{C} 209^{+}}, \mathrm{Fc} \varepsilon \mathrm{RI}^{\text {bright }}, \mathrm{IgE}^{+}, \mathrm{HLA}^{\mathrm{D}} \mathrm{DR}^{\text {bright }}$, and negative for lineage markers $(89,136,140,143)$. After epicutaneous exposure of AD patients to aero-antigens and food antigens, in most cases an eczematous reaction ensued, in which case FceR1bearing IDEC were found in the epidermis within $72 \mathrm{~h}$ (144). Upon ligation of FceRI, these IDEC are able to produce CCL3, IL-1, IL16, but also IL-12p70 and IL-18 (141). These latter two cytokines induce $T_{H} 1$ polarization and production of IFN $\gamma$, thus likely contributing to the switch from $\mathrm{T}_{\mathrm{H}} 2$ to $\mathrm{T}_{\mathrm{H}} 1$ that leads to the chronic phase of the disease (133).

Together, also for $\mathrm{AD}$, there seems to be a key role for $\mathrm{DC}$ in the pathogenesis of the disease. In this case, the main role during genesis of the disease is assigned to LC, while pDC hardly play a role. For the chronic phase again there is an infDC type, but one different from the infDC type prominent in psoriasis. Interestingly, although skin of $\mathrm{AD}$ and psoriasis patients harbors DC subsets with different characteristics, ex vivo DC subsets from both disease groups show similar T-cell polarizing ability (145). In contrast, chemokine expression differs markedly between the two diseases, showing $\mathrm{T}_{\mathrm{H}} 2$-associated and some $\mathrm{T}_{\mathrm{H}} 1$-associated chemokines in lesional AD skin, while demonstrating mostly $\mathrm{T}_{\mathrm{H}} 1 / \mathrm{T}_{\mathrm{H}} 17$-associated chemokines in psoriasis (145). These data would suggest that skin DC do not directly drive T-cell polarization but contribute indirectly by shaping the local chemokine environment and attracting and further stimulating specific subsets of $\mathrm{T}$ cells that are recruited to in the skin. It is important to realize however that DC responses largely depend on the nature and extend of the stimulus. While ex vivo triggered DC subsets may show a high degree of functional plasticity, the tissue context and local inflammatory environment likely polarize and restrict their in vivo function.

\section{CONCLUSION}

Over the past years, there has been important progress in our understanding of human DC subsets and their functional roles in 
steady-state conditions. With transcriptional profiling data distinct subsets of circulating and tissue DC have been defined and their relationships with monocytes and macrophages have been further elucidated. In inflammatory conditions, plasticity, and versatility of the DC and monocyte compartments is revealed with local signals driving their differentiation and function. The challenge ahead is to define the contributions of DC subsets in these (pathogenic) inflammatory conditions and its resolution.

\section{AUTHOR CONTRIBUTIONS}

Both Arjan Boltjes and Femke van Wijk: conception and design, drafting, and revising. Both authors approve of the final version to be published and agree to be accountable for all aspects of the work.

\section{ACKNOWLEDGMENTS}

We thank Dr. Stefan Nierkens for critically reading the manuscript.

\section{REFERENCES}

1. Haniffa M, Collin M, Ginhoux F. Ontogeny and functional specialization of dendritic cells in human and mouse. Adv Immunol (2013) 120:1-49. doi:10.1016/B978-0-12-417028-5.00001-6

2. Schlitzer A, Ginhoux F. Organization of the mouse and human DC network. Curr Opin Immunol (2014) 26:90-9. doi:10.1016/j.coi.2013.11.002

3. Dzionek A, Fuchs A, Schmidt P, Cremer S, Zysk M, Miltenyi S, et al. BDCA-2, BDCA-3, and BDCA-4: three markers for distinct subsets of dendritic cells in human peripheral blood. J Immunol (2000) 165:6037-46.

4. Ziegler-Heitbrock L, Ancuta P, Crowe S, Dalod M, Grau V, Hart DN, et al. Nomenclature of monocytes and dendritic cells in blood. Blood (2010) 116:e74-80. doi:10.1182/blood-2010-02-258558

5. Velasquez-Lopera MM, Correa LA, Garcia LF. Human spleen contains different subsets of dendritic cells and regulatory T lymphocytes. Clin Exp Immunol (2008) 154:107-14. doi:10.1111/j.1365-2249.2008.03734.x

6. Mittag D, Proietto AI, Loudovaris T, Mannering SI, Vremec D, Shortman K, et al. Human dendritic cell subsets from spleen and blood are similar in phenotype and function but modified by donor health status. J Immunol (2011) 186:6207-17. doi:10.4049/jimmunol.1002632

7. Lindstedt M, Lundberg K, Borrebaeck CA. Gene family clustering identifies functionally associated subsets of human in vivo blood and tonsillar dendritic cells. J Immunol (2005) 175:4839-46.

8. Robbins SH, Walzer T, Dembele D, Thibault C, Defays A, Bessou G, et al. Novel insights into the relationships between dendritic cell subsets in human and mouse revealed by genome-wide expression profiling. Genome Biol (2008) 9:R17. doi:10.1186/gb-2008-9-1-r17

9. MacDonald KP, Munster DJ, Clark GJ, Dzionek A, Schmitz J, Hart DN. Characterization of human blood dendritic cell subsets. Blood (2002) 100:4512-20. doi:10.1182/blood-2001-11-0097

10. Segura E, Valladeau-Guilemond J, Donnadieu MH, Sastre-Garau X, Soumelis V, Amigorena S. Characterization of resident and migratory dendritic cells in human lymph nodes. J Exp Med (2012) 209:653-60. doi:10.1084/jem.20111457

11. Banchereau J, Pulendran B, Steinman R, Palucka K. Will the making of plasmacytoid dendritic cells in vitro help unravel their mysteries? J Exp Med (2000) 192:F39-44. doi:10.1084/jem.192.12.F39

12. Schlitzer A, McGovern N, Teo P, Zelante T, Atarashi K, Low D, et al. IRF4 transcription factor-dependent $\mathrm{CD} 11 \mathrm{~b}+$ dendritic cells in human and mouse control mucosal IL-17 cytokine responses. Immunity (2013) 38:970-83. doi: 10.1016/j.immuni.2013.04.011

13. Haniffa M, Shin A, Bigley V, McGovern N, Teo P, See P, et al. Human tissues contain CD141hi cross-presenting dendritic cells with functional homology to mouse CD103+ nonlymphoid dendritic cells. Immunity (2012) 37:60-73. doi:10.1016/j.immuni.2012.04.012

14. Hashimoto D, Miller J, Merad M. Dendritic cell and macrophage heterogeneity in vivo. Immunity (2011) 35:323-35. doi:10.1016/j.immuni.2011.09.007
15. Belz GT, Nutt SL. Transcriptional programming of the dendritic cell network. Nat Rev Immunol (2012) 12:101-13. doi:10.1038/nri3149

16. Schraml BU, van Blijswijk J, Zelenay S, Whitney PG, Filby A, Acton SE, et al. Genetic tracing via DNGR-1 expression history defines dendritic cells as a hematopoietic lineage. Cell (2013) 154:843-58. doi:10.1016/j.cell.2013.07.014

17. Naik SH, Perie L, Swart E, Gerlach C, van Rooij N, de Boer RJ, et al. Diverse and heritable lineage imprinting of early haematopoietic progenitors. Nature (2013) 496:229-32. doi:10.1038/nature12013

18. Doulatov S, Notta F, Eppert K, Nguyen LT, Ohashi PS, Dick JE. Revised map of the human progenitor hierarchy shows the origin of macrophages and dendritic cells in early lymphoid development. Nat Immunol (2010) 11:585-93. doi:10.1038/ni.1889

19. Collin M, Bigley V, Haniffa M, Hambleton S. Human dendritic cell deficiency: the missing ID? Nat Rev Immunol (2011) 11:575-83. doi:10.1038/nri3046

20. Nizzoli G, Krietsch J, Weick A, Steinfelder S, Facciotti F, Gruarin P, et al. Human $\mathrm{CD} 1 \mathrm{c}+$ dendritic cells secrete high levels of IL-12 and potently prime cytotoxic T-cell responses. Blood (2013) 122:932-42. doi:10.1182/blood-2013-04495424

21. Randolph GJ, Ochando J, Partida-Sanchez S. Migration of dendritic cell subsets and their precursors. Annu Rev Immunol (2008) 26:293-316. doi:10.1146/ annurev.immunol.26.021607.090254

22. Zawada AM, Rogacev KS, Rotter B, Winter P, Marell RR, Fliser D, et al. SuperSAGE evidence for CD14++CD16+ monocytes as a third monocyte subset. Blood (2011) 118:e50-61. doi:10.1182/blood-2011-01-326827

23. Cros J, Cagnard N, Woollard K, Patey N, Zhang SY, Senechal B, et al. Human CD14dim monocytes patrol and sense nucleic acids and viruses via TLR7 and TLR8 receptors. Immunity (2010) 33:375-86. doi:10.1016/j.immuni.2010. 08.012

24. Schakel K, Kannagi R, Kniep B, Goto Y, Mitsuoka C, Zwirner J, et al. 6Sulfo LacNAc, a novel carbohydrate modification of PSGL-1, defines an inflammatory type of human dendritic cells. Immunity (2002) 17:289-301. doi:10.1016/S1074-7613(02)00393-X

25. Hansel A, Gunther C, Ingwersen J, Starke J, Schmitz M, Bachmann M, et al. Human slan (6-sulfo LacNAc) dendritic cells are inflammatory dermal dendritic cells in psoriasis and drive strong TH17/TH1 T-cell responses. J Allergy Clin Immunol (2011) 127:787-94. doi:10.1016/j.jaci.2010.12.009

26. Jakubzick C, Gautier EL, Gibbings SL, Sojka DK, Schlitzer A, Johnson TE, et al. Minimal differentiation of classical monocytes as they survey steady-state tissues and transport antigen to lymph nodes. Immunity (2013) 39:599-610. doi:10.1016/j.immuni.2013.08.007

27. Davies LC, Jenkins SJ, Allen JE, Taylor PR. Tissue-resident macrophages. Nat Immunol (2013) 14:986-95. doi:10.1038/ni.2705

28. Boltjes A, Movita D, Boonstra A, Woltman AM. The role of Kupffer cells in viral hepatitis. J Hepatol (2014). (in press).

29. Schiwon M, Weisheit C, Franken L, Gutweiler S, Dixit A, Meyer-Schwesinger C, et al. Crosstalk between sentinel and helper macrophages permits neutrophil migration into infected uroepithelium. Cell (2014) 156:456-68. doi:10.1016/j. cell.2014.01.006

30. Schulz C, Gomez PE, Chorro L, Szabo-Rogers H, Cagnard N, Kierdorf K, et al. A lineage of myeloid cells independent of Myb and hematopoietic stem cells. Science (2012) 336:86-90. doi:10.1126/science.1219179

31. Guilliams M, De Kleer I, Henri S, Post S, Vanhoutte L, De Prijck S, et al. Alveolar macrophages develop from fetal monocytes that differentiate into long-lived cells in the first week of life via GM-CSF. J Exp Med (2013) 210:1977-92. doi:10.1084/jem.20131199

32. Hashimoto D, Chow A, Noizat C, Teo P, Beasley MB, Leboeuf M, et al. Tissueresident macrophages self-maintain locally throughout adult life with minimal contribution from circulating monocytes. Immunity (2013) 38:792-804. doi:10.1016/j.immuni.2013.04.004

33. Jenkins SJ, Ruckerl D, Cook PC, Jones LH, Finkelman FD, van Rooijen $\mathrm{N}$, et al. Local macrophage proliferation, rather than recruitment from the blood, is a signature of TH2 inflammation. Science (2011) 332:1284-8. doi:10.1126/science.1204351

34. Zigmond E, Jung S. Intestinal macrophages: well educated exceptions from the rule. Trends Immunol (2013) 34:162-8. doi:10.1016/j.it.2013.02.001

35. Bigley V, Haniffa M, Doulatov S, Wang XN, Dickinson R, McGovern N, et al. The human syndrome of dendritic cell, monocyte, B and NK lymphoid deficiency. J Exp Med (2011) 208:227-34. doi:10.1084/jem.20101459 
36. Hambleton S, Salem S, Bustamante J, Bigley V, Boisson-Dupuis S, Azevedo J, et al. IRF8 mutations and human dendritic-cell immunodeficiency. $N$ Engl J Med (2011) 365:127-38. doi:10.1056/NEJMoa1100066

37. Vinh DC, Patel SY, Uzel G, Anderson VL, Freeman AF, Olivier KN, et al. Autosomal dominant and sporadic monocytopenia with susceptibility to mycobacteria, fungi, papillomaviruses, and myelodysplasia. Blood (2010) 115:1519-29. doi:10.1182/blood-2009-03-208629

38. Haniffa M, Ginhoux F, Wang XN, Bigley V, Abel M, Dimmick I, et al. Differential rates of replacement of human dermal dendritic cells and macrophages during hematopoietic stem cell transplantation. J Exp Med (2009) 206:371-85. doi: $10.1084 /$ jem. 20081633

39. Thomas ED, Ramberg RE, Sale GE, Sparkes RS, Golde DW. Direct evidence for a bone marrow origin of the alveolar macrophage in man. Science (1976) 192:1016-8. doi:10.1126/science.775638

40. Auffray C, Fogg D, Garfa M, Elain G, Join-Lambert O, Kayal S, et al. Monitoring of blood vessels and tissues by a population of monocytes with patrolling behavior. Science (2007) 317:666-70. doi:10.1126/science.1142883

41. Geissmann F, Jung S, Littman DR. Blood monocytes consist of two principal subsets with distinct migratory properties. Immunity (2003) 19:71-82. doi:10.1016/S1074-7613(03)00174-2

42. Lichtnekert J, Kawakami T, Parks WC, Duffield JS. Changes in macrophage phenotype as the immune response evolves. Curr Opin Pharmacol (2013) 13:555-64. doi:10.1016/j.coph.2013.05.013

43. Mosser DM, Edwards JP. Exploring the full spectrum of macrophage activation. Nat Rev Immunol (2008) 8:958-69. doi:10.1038/nri2448

44. Cella M, Jarrossay D, Facchetti F, Alebardi O, Nakajima H, Lanzavecchia A, et al. Plasmacytoid monocytes migrate to inflamed lymph nodes and produce large amounts of type I interferon. Nat Med (1999) 5:919-23. doi:10.1038/11360

45. Mathan TS, Figdor CG, Buschow SI. Human plasmacytoid dendritic cells: from molecules to intercellular communication network. Front Immunol (2013) 4:372. doi:10.3389/fimmu.2013.00372

46. Coccia EM, Severa M, Giacomini E, Monneron D, Remoli ME, Julkunen I, et al. Viral infection and Toll-like receptor agonists induce a differential expression of type I and lambda interferons in human plasmacytoid and monocyte-derived dendritic cells. Eur J Immunol (2004) 34:796-805. doi:10.1002/eji.200324610

47. Yin Z, Dai J, Deng J, Sheikh F, Natalia M, Shih T, et al. Type III IFNs are produced by and stimulate human plasmacytoid dendritic cells. J Immunol (2012) 189:2735-45. doi:10.4049/jimmunol.1102038

48. Martin-Gayo E, Sierra-Filardi E, Corbi AL, Toribio ML. Plasmacytoid dendritic cells resident in human thymus drive natural Treg cell development. Blood (2010) 115:5366-75. doi:10.1182/blood-2009-10-248260

49. Ito T, Hanabuchi S, Wang YH, Park WR, Arima K, Bover L, et al. Two functional subsets of FOXP3+ regulatory T cells in human thymus and periphery. Immunity (2008) 28:870-80. doi:10.1016/j.immuni.2008.03.018

50. Poulin LF, Salio M, Griessinger E, Anjos-Afonso F, Craciun L, Chen JL, et al. Characterization of human DNGR-1+ BDCA3+ leukocytes as putative equivalents of mouse CD8alpha+ dendritic cells. J Exp Med (2010) 207:1261-71. doi:10.1084/jem.20092618

51. Jongbloed SL, Kassianos AJ, McDonald KJ, Clark GJ, Ju X, Angel CE, et al. Human CD141+ (BDCA-3)+ dendritic cells (DCs) represent a unique myeloid DC subset that cross-presents necrotic cell antigens. J Exp Med (2010) 207:1247-60. doi:10.1084/jem.20092140

52. Crozat K, Guiton R, Contreras V, Feuillet V, Dutertre CA, Ventre E, et al. The XC chemokine receptor 1 is a conserved selective marker of mammalian cells homologous to mouse CD8alpha+ dendritic cells. J Exp Med (2010) 207:1283-92. doi:10.1084/jem.20100223

53. Bachem A, Guttler S, Hartung E, Ebstein F, Schaefer M, Tannert A, et al. Superior antigen cross-presentation and XCR1 expression define human CD11c+CD141+ cells as homologues of mouse CD8+ dendritic cells. J Exp Med (2010) 207:1273-81. doi:10.1084/jem.20100348

54. Hemont C, Neel A, Heslan M, Braudeau C, Josien R. Human blood mDC subsets exhibit distinct TLR repertoire and responsiveness. J Leukoc Biol (2013) 93:599-609. doi:10.1189/jlb.0912452

55. Lauterbach H, Bathke B, Gilles S, Traidl-Hoffmann C, Luber CA, Fejer G, et al. Mouse CD8alpha+ DCs and human BDCA3+ DCs are major producers of IFN-lambda in response to poly IC. J Exp Med (2010) 207:2703-17. doi:10.1084/jem.20092720
56. McCurley N, Mellman I. Monocyte-derived dendritic cells exhibit increased levels of lysosomal proteolysis as compared to other human dendritic cell populations. PLoS One (2010) 5:e11949. doi:10.1371/journal.pone.0011949

57. Klechevsky E, Morita R, Liu M, Cao Y, Coquery S, Thompson-Snipes L, et al. Functional specializations of human epidermal Langerhans cells and CD14+ dermal dendritic cells. Immunity (2008) 29:497-510. doi:10.1016/j.immuni. 2008.07.013

58. Kelly A, Fahey R, Fletcher JM, Keogh C, Carroll AG, Siddachari R, et al. $\mathrm{CD} 141(+)$ myeloid dendritic cells are enriched in healthy human liver. J Hepatol (2014) 60:135-42. doi:10.1016/j.jhep.2013.08.007

59. Jung S, Unutmaz D, Wong P, Sano G, De los Santos K, Sparwasser T, et al. In vivo depletion of CD11c+ dendritic cells abrogates priming of CD8+ $\mathrm{T}$ cells by exogenous cell-associated antigens. Immunity (2002) 17:211-20. doi:10.1016/S1074-7613(02)00365-5

60. Joffre OP, Segura E, Savina A, Amigorena S. Cross-presentation by dendritic cells. Nat Rev Immunol (2012) 12:557-69. doi:10.1038/nri3254

61. Pooley JL, Heath WR, Shortman K. Cutting edge: intravenous soluble antigen is presented to CD4 T cells by CD8- dendritic cells, but cross-presented to CD8 T cells by CD8+ dendritic cells. J Immunol (2001) 166:5327-30.

62. Shortman K, Heath WR. The CD8+ dendritic cell subset. Immunol Rev (2010) 234:18-31. doi:10.1111/j.0105-2896.2009.00870.x

63. Nierkens S, Tel J, Janssen E, Adema GJ. Antigen cross-presentation by dendritic cell subsets: one general or all sergeants? Trends Immunol (2013) 34:361-70. doi:10.1016/j.it.2013.02.007

64. Flinsenberg TW, Compeer EB, Koning D, Klein M, Amelung FJ, van Baarle D, et al. Fcgamma receptor antigen targeting potentiates cross-presentation by human blood and lymphoid tissue BDCA-3+ dendritic cells. Blood (2012) 120:5163-72. doi:10.1182/blood-2012-06-434498

65. Cohn L, Chatterjee B, Esselborn F, Smed-Sorensen A, Nakamura N, Chalouni $\mathrm{C}$, et al. Antigen delivery to early endosomes eliminates the superiority of human blood BDCA3+ dendritic cells at cross presentation. J Exp Med (2013) 210:1049-63. doi:10.1084/jem.20121251

66. Segura E, Durand M, Amigorena S. Similar antigen cross-presentation capacity and phagocytic functions in all freshly isolated human lymphoid organresident dendritic cells. J Exp Med (2013) 210:1035-47. doi:10.1084/jem. 20121103

67. Manh TP, Alexandre Y, Baranek T, Crozat K, Dalod M. Plasmacytoid, conventional, and monocyte-derived dendritic cells undergo a profound and convergent genetic reprogramming during their maturation. Eur J Immunol (2013) 43:1706-15. doi:10.1002/eji.201243106

68. Randolph GJ, Beaulieu S, Lebecque S, Steinman RM, Muller WA. Differentiation of monocytes into dendritic cells in a model of transendothelial trafficking. Science (1998) 282:480-3. doi:10.1126/science.282.5388.480

69. Sallusto F, Lanzavecchia A. Efficient presentation of soluble antigen by cultured human dendritic cells is maintained by granulocyte/macrophage colonystimulating factor plus interleukin 4 and downregulated by tumor necrosis factor alpha. J Exp Med (1994) 179:1109-18. doi:10.1084/jem.179.4.1109

70. Geissmann F, Revy P, Brousse N, Lepelletier Y, Folli C, Durandy A, et al. Retinoids regulate survival and antigen presentation by immature dendritic cells. J Exp Med (2003) 198:623-34. doi:10.1084/jem.20030390

71. Serbina NV, Salazar-Mather TP, Biron CA, Kuziel WA, Pamer EG. TNF/iNOSproducing dendritic cells mediate innate immune defense against bacterial infection. Immunity (2003) 19:59-70. doi:10.1016/S1074-7613(03)00171-7

72. Leon B, Lopez-Bravo M, Ardavin C. Monocyte-derived dendritic cells formed at the infection site control the induction of protective $\mathrm{T}$ helper 1 responses against Leishmania. Immunity (2007) 26:519-31. doi:10.1016/j.immuni.2007. 01.017

73. Hespel C, Moser M. Role of inflammatory dendritic cells in innate and adaptive immunity. Eur J Immunol (2012) 42:2535-43. doi:10.1002/eji.201242480

74. Plantinga M, Guilliams M, Vanheerswynghels M, Deswarte K, Branco-Madeira F, Toussaint W, et al. Conventional and monocyte-derived CD11b $(+)$ dendritic cells initiate and maintain T helper 2 cell-mediated immunity to house dust mite allergen. Immunity (2013) 38:322-35. doi:10.1016/j.immuni.2012.10.016

75. Beitnes AC, Raki M, Brottveit M, Lundin KE, Jahnsen FL, Sollid LM. Rapid accumulation of CD14+CD11c+ dendritic cells in gut mucosa of celiac disease after in vivo gluten challenge. PLoS One (2012) 7:e33556. doi:10.1371/journal. pone.0033556 
76. GeurtsvanKessel CH, Lambrecht BN. Division of labor between dendritic cell subsets of the lung. Mucosal Immunol (2008) 1:442-50. doi:10.1038/mi.2008.39

77. Lin KL, Suzuki Y, Nakano H, Ramsburg E, Gunn MD. CCR2+ monocytederived dendritic cells and exudate macrophages produce influenza-induced pulmonary immune pathology and mortality. J Immunol (2008) 180:2562-72.

78. Segura E, Touzot M, Bohineust A, Cappuccio A, Chiocchia G, Hosmalin A, et al. Human inflammatory dendritic cells induce Th17 cell differentiation. Immunity (2013) 38:336-48. doi:10.1016/j.immuni.2012.10.018

79. Wehrens EJ, Mijnheer G, Duurland CL, Klein M, Meerding J, van Loosdregt $\mathrm{J}$, et al. Functional human regulatory $\mathrm{T}$ cells fail to control autoimmune inflammation due to $\mathrm{PKB} / \mathrm{c}$-akt hyperactivation in effector cells. Blood (2011) 118:3538-48. doi:10.1182/blood-2010-12-328187

80. Wehrens EJ, Prakken BJ, van Wijk F. T cells out of control - impaired immune regulation in the inflamed joint. Nat Rev Rheumatol (2013) 9:34-42. doi:10.1038/nrrheum.2012.149

81. Ganguly D, Haak S, Sisirak V, Reizis B. The role of dendritic cells in autoimmunity. Nat Rev Immunol (2013) 13:566-77. doi:10.1038/nri3477

82. Bon L, van Affandi J, Broen J, Christmann RB, Marijnissen RJ, Stawski L, et al. Proteome-wide analysis and CXCL4 as a biomarker in systemic sclerosis. $\mathrm{N}$ Engl J Med (2014) 370:433-43. doi:10.1056/NEJMoa1114576

83. Gilliet M, Cao W, Liu YJ. Plasmacytoid dendritic cells: sensing nucleic acids in viral infection and autoimmune diseases. Nat Rev Immunol (2008) 8:594-606. doi: $10.1038 /$ nri2358

84. Gottenberg JE, Cagnard N, Lucchesi C, Letourneur F, Mistou S, Lazure T, et al. Activation of IFN pathways and plasmacytoid dendritic cell recruitment in target organs of primary Sjogren's syndrome. Proc Natl Acad Sci U S A (2006) 103:2770-5. doi:10.1073/pnas.0510837103

85. Lopez De Padilla CM, Vallejo AN, McNallan KT, Vehe R, Smith SA, Dietz $\mathrm{AB}$, et al. Plasmacytoid dendritic cells in inflamed muscle of patients with juvenile dermatomyositis. Arthritis Rheum (2007) 56:1658-68. doi:10.1002/ art.22558

86. Nestle FO, Di Meglio MP, Qin JZ, Nickoloff BJ. Skin immune sentinels in health and disease. Nat Rev Immunol (2009) 9:679-91. doi:10.1038/nri2622

87. Zaba LC, Krueger JG, Lowes MA. Resident and "inflammatory" dendritic cells in human skin. J Invest Dermatol (2009) 129:302-8. doi:10.1038/jid.2008.225

88. Merad M, Ginhoux F, Collin M. Origin, homeostasis and function of Langerhans cells and other langerin-expressing dendritic cells. Nat Rev Immunol (2008) 8:935-47. doi:10.1038/nri2455

89. Wollenberg A, Kraft S, Hanau D, Bieber T. Immunomorphological and ultrastructural characterization of Langerhans cells and a novel, inflammatory dendritic epidermal cell (IDEC) population in lesional skin of atopic eczema. J Invest Dermatol (1996) 106:446-53. doi:10.1111/1523-1747.ep12343596

90. Merad M, Manz MG, Karsunky H, Wagers A, Peters W, Charo I, et al. Langerhans cells renew in the skin throughout life under steady-state conditions. Nat Immunol (2002) 3:1135-41. doi:10.1038/ni852

91. Ginhoux F, Tacke F, Angeli V, Bogunovic M, Loubeau M, Dai XM, et al. Langerhans cells arise from monocytes in vivo. Nat Immunol (2006) 7:265-73. doi:10.1038/ni1307

92. Klechevsky E. Human dendritic cells - stars in the skin. Eur J Immunol (2013) 43:3147-55. doi:10.1002/eji.201343790

93. Angel CE, Chen CJ, Horlacher OC, Winkler S, John T, Browning J, et al. Distinctive localization of antigen-presenting cells in human lymph nodes. Blood (2009) 113:1257-67. doi:10.1182/blood-2008-06-165266

94. Stoitzner P, Tripp CH, Eberhart A, Price KM, Jung JY, Bursch L, et al. Langerhans cells cross-present antigen derived from skin. Proc Natl Acad Sci U S A (2006) 103:7783-8. doi:10.1073/pnas.0509307103

95. Angel CE, Lala A, Chen CJ, Edgar SG, Ostrovsky LL, Dunbar PR. CD14+ antigen-presenting cells in human dermis are less mature than their $\mathrm{CDla}+$ counterparts. Int Immunol (2007) 19:1271-9. doi:10.1093/intimm/dxm096

96. Harman AN, Bye CR, Nasr N, Sandgren KJ, Kim M, Mercier SK, et al. Identification of lineage relationships and novel markers of blood and skin human dendritic cells. J Immunol (2013) 190:66-79. doi:10.4049/jimmunol.1200779

97. Angel CE, George E, Brooks AE, Ostrovsky LL, Brown TL, Dunbar PR. Cutting edge: $\mathrm{CD} 1 \mathrm{a}+$ antigen-presenting cells in human dermis respond rapidly to CCR7 ligands. J Immunol (2006) 176:5730-4.

98. Nestle FO, Turka LA, Nickoloff BJ. Characterization of dermal dendritic cells in psoriasis. Autostimulation of T lymphocytes and induction of Th1 type cytokines. J Clin Invest (1994) 94:202-9. doi:10.1172/JCI117308
99. Larregina AT, Morelli AE, Spencer LA, Logar AJ, Watkins SC, Thomson AW, et al. Dermal-resident CD14+ cells differentiate into Langerhans cells. Nat Immunol (2001) 2:1151-8. doi:10.1038/ni731

100. Chu CC, Ali N, Karagiannis P, Di Meglio P, Skowera A, Napolitano L, et al. Resident CD141 (BDCA3)+ dendritic cells in human skin produce IL-10 and induce regulatory T cells that suppress skin inflammation. J Exp Med (2012) 209:935-45. doi:10.1084/jem.20112583

101. Perera GK, Di Meglio P, Nestle FO. Psoriasis. Annu Rev Pathol (2012) 7:385-422. doi:10.1146/annurev-pathol-011811-132448

102. Chu CC, Di Meglio P, Nestle FO. Harnessing dendritic cells in inflammatory skin diseases. Semin Immunol (2011) 23:28-41. doi:10.1016/j.smim.2011. 01.006

103. Schmid P, Itin P, Cox D, McMaster GK, Horisberger MA. The type I interferon system is locally activated in psoriatic lesions. J Interferon Res (1994) 14:229-34. doi:10.1089/jir.1994.14.229

104. Nestle FO, Conrad C, Tun-Kyi A, Homey B, Gombert M, Boyman O, et al. Plasmacytoid predendritic cells initiate psoriasis through interferon-alpha production. J Exp Med (2005) 202:135-43. doi:10.1084/jem.20050500

105. Wollenberg A, Wagner M, Gunther S, Towarowski A, Tuma E, Moderer M, et al. Plasmacytoid dendritic cells: a new cutaneous dendritic cell subset with distinct role in inflammatory skin diseases. J Invest Dermatol (2002) 119:1096-102. doi:10.1046/j.1523-1747.2002.19515.x

106. Heier I, Soyland E, Krogstad AL, Rodriguez-Gallego C, Nenseter MS, Jahnsen FL. Sun exposure rapidly reduces plasmacytoid dendritic cells and inflammatory dermal dendritic cells in psoriatic skin. Br J Dermatol (2011) 165:792-801. doi:10.1111/j.1365-2133.2011.10430.x

107. Ganguly D, Chamilos G, Lande R, Gregorio J, Meller S, Facchinetti V, et al. SelfRNA-antimicrobial peptide complexes activate human dendritic cells through TLR7 and TLR8. J Exp Med (2009) 206:1983-94. doi:10.1084/jem.20090480

108. Lande R, Gregorio J, Facchinetti V, Chatterjee B, Wang YH, Homey B, et al. Plasmacytoid dendritic cells sense self-DNA coupled with antimicrobial peptide. Nature (2007) 449:564-9. doi:10.1038/nature06116

109. Garcia-Romo GS, Caielli S, Vega B, Connolly J, Allantaz F, Xu Z, et al. Netting neutrophils are major inducers of type I IFN production in pediatric systemic lupus erythematosus. Sci Transl Med (2011) 3:73ra20. doi:10.1126/ scitranslmed.3001201

110. Skrzeczynska-Moncznik J, Wlodarczyk A, Banas M, Kwitniewski M, Zabieglo K, Kapinska-Mrowiecka M, et al. DNA structures decorated with cathepsin $\mathrm{G} /$ secretory leukocyte proteinase inhibitor stimulate IFNI production by plasmacytoid dendritic cells. Am J Clin Exp Immunol (2013) 2:186-94.

111. Lande R, Ganguly D, Facchinetti V, Frasca L, Conrad C, Gregorio J, et al. Neutrophils activate plasmacytoid dendritic cells by releasing self-DNA-peptide complexes in systemic lupus erythematosus. Sci Transl Med (2011) 3:73ra19. doi:10.1126/scitranslmed.3001180

112. Gilliet M, Conrad C, Geiges M, Cozzio A, Thurlimann W, Burg G, et al. Psoriasis triggered by toll-like receptor 7 agonist imiquimod in the presence of dermal plasmacytoid dendritic cell precursors. Arch Dermatol (2004) 140:1490-5. doi:10.1001/archderm.140.12.1490

113. Urosevic M, Dummer R, Conrad C, Beyeler M, Laine E, Burg G, et al. Diseaseindependent skin recruitment and activation of plasmacytoid predendritic cells following imiquimod treatment. J Natl Cancer Inst (2005) 97:1143-53. doi:10.1093/jnci/dji207

114. Albanesi C, Scarponi C, Pallotta S, Daniele R, Bosisio D, Madonna S, et al. Chemerin expression marks early psoriatic skin lesions and correlates with plasmacytoid dendritic cell recruitment. J Exp Med (2009) 206:249-58. doi:10.1084/jem.20080129

115. Skrzeczynska-Moncznik J, Wawro K, Stefanska A, Oleszycka E, Kulig P, Zabel BA, et al. Potential role of chemerin in recruitment of plasmacytoid dendritic cells to diseased skin. Biochem Biophys Res Commun (2009) 380:323-7. doi:10.1016/j.bbrc.2009.01.071

116. Cerio R, Griffiths CE, Cooper KD, Nickoloff BJ, Headington JT. Characterization of factor XIIIa positive dermal dendritic cells in normal and inflamed skin. Br J Dermatol (1989) 121:421-31. doi:10.1111/j.1365-2133. 1989.tb15509.x

117. Zaba LC, Cardinale I, Gilleaudeau P, Sullivan-Whalen M, Suarez-Farinas M, Fuentes-Duculan J, et al. Amelioration of epidermal hyperplasia by TNF inhibition is associated with reduced Th17 responses. J Exp Med (2007) 204:3183-94. doi:10.1084/jem.20071094 
118. Austin LM, Ozawa M, Kikuchi T, Walters IB, Krueger JG. The majority of epidermal $\mathrm{T}$ cells in psoriasis vulgaris lesions can produce type 1 cytokines, interferon-gamma, interleukin-2, and tumor necrosis factor-alpha, defining TC1 (cytotoxic T lymphocyte) and TH1 effector populations: a type 1 differentiation bias is also measured in circulating blood T cells in psoriatic patients. J Invest Dermatol (1999) 113:752-9.

119. Ferenczi K, Burack L, Pope M, Krueger JG, Austin LM. CD69, HLA-DR and the IL-2R identify persistently activated $\mathrm{T}$ cells in psoriasis vulgaris lesional skin: blood and skin comparisons by flow cytometry. J Autoimmun (2000) 14:63-78. doi:10.1006/jaut.1999.0343

120. Zaba LC, Fuentes-Duculan J, Eungdamrong NJ, Abello MV, Novitskaya I, Pierson KC, et al. Psoriasis is characterized by accumulation of immunostimulatory and Th1/Th17 cell-polarizing myeloid dendritic cells. J Invest Dermatol (2009) 129:79-88. doi:10.1038/jid.2008.194

121. Guttman-Yassky E, Lowes MA, Fuentes-Duculan J, Zaba LC, Cardinale I, Nograles KE, et al. Low expression of the IL-23/Th17 pathway in atopic dermatitis compared to psoriasis. J Immunol (2008) 181:7420-7.

122. Lee E, Trepicchio WL, Oestreicher JL, Pittman D, Wang F, Chamian F, et al. Increased expression of interleukin 23 p19 and p40 in lesional skin of patients with psoriasis vulgaris. J Exp Med (2004) 199:125-30. doi:10.1084/ jem.20030451

123. Piskin G, Sylva-Steenland RM, Bos JD, Teunissen MB. In vitro and in situ expression of IL-23 by keratinocytes in healthy skin and psoriasis lesions: enhanced expression in psoriatic skin. J Immunol (2006) 176:1908-15.

124. Yawalkar N, Karlen S, Hunger R, Brand CU, Braathen LR. Expression of interleukin-12 is increased in psoriatic skin. J Invest Dermatol (1998) 111:1053-7. doi:10.1046/j.1523-1747.1998.00446.x

125. Yawalkar N, Tscharner GG, Hunger RE, Hassan AS. Increased expression of IL-12p70 and IL-23 by multiple dendritic cell and macrophage subsets in plaque psoriasis. J Dermatol Sci (2009) 54:99-105. doi:10.1016/j.jdermsci.2009. 01.003

126. Lowes MA, Chamian F, Abello MV, Fuentes-Duculan J, Lin SL, Nussbaum R, et al. Increase in TNF-alpha and inducible nitric oxide synthase-expressing dendritic cells in psoriasis and reduction with efalizumab (anti-CD11a). Proc Natl Acad Sci U S A (2005) 102:19057-62. doi:10.1073/pnas.0509736102

127. Lowes MA, Kikuchi T, Fuentes-Duculan J, Cardinale I, Zaba LC, Haider AS, et al. Psoriasis vulgaris lesions contain discrete populations of Th1 and Th17 T cells. J Invest Dermatol (2008) 128:1207-11. doi:10.1038/sj.jid.5701213

128. Wilson NJ, Boniface K, Chan JR, McKenzie BS, Blumenschein WM, Mattson JD, et al. Development, cytokine profile and function of human interleukin 17-producing helper T cells. Nat Immunol (2007) 8:950-7. doi:10.1038/ ni1497

129. Cumberbatch M, Singh M, Dearman RJ, Young HS, Kimber I, Griffiths CE. Impaired Langerhans cell migration in psoriasis. J Exp Med (2006) 203:953-60. doi:10.1084/jem.20052367

130. Shaw FL, Kimber I, Begum R, Cumberbatch M, Dearman RJ, Griffiths CE. No impairment of monocyte-derived Langerhans cell phenotype or function in early-onset psoriasis. Clin Exp Dermatol (2012) 37:40-7. doi:10.1111/j.13652230.2011.04172.x

131. Shaw FL, Cumberbatch M, Kleyn CE, Begum R, Dearman RJ, Kimber I, et al. Langerhans cell mobilization distinguishes between early-onset and late-onset psoriasis. J Invest Dermatol (2010) 130:1940-2. doi:10.1038/jid.2010.57

132. Zaba LC, Fuentes-Duculan J, Eungdamrong NJ, Johnson-Huang LM, Nograles KE, White TR, et al. Identification of TNF-related apoptosis-inducing ligand and other molecules that distinguish inflammatory from resident dendritic cells in patients with psoriasis. J Allergy Clin Immunol (2010) 125:1261-8. doi:10.1016/j.jaci.2010.03.018

133. Bieber T. Atopic dermatitis. N Engl J Med (2008) 358:1483-94. doi:10.1056/ NEJMra074081

134. Grewe M, Walther S, Gyufko K, Czech W, Schopf E, Krutmann J. Analysis of the cytokine pattern expressed in situ in inhalant allergen patch test reactions of atopic dermatitis patients. J Invest Dermatol (1995) 105:407-10. doi:10.1111/1523-1747.ep12321078
135. Grewe M, Bruijnzeel-Koomen CA, Schopf E, Thepen T, Langeveld-Wildschut AG, Ruzicka T, et al. A role for Th1 and Th2 cells in the immunopathogenesis of atopic dermatitis. Immunol Today (1998) 19:359-61. doi:10.1016/S01675699(98)01285-7

136. Guttman-Yassky E, Lowes MA, Fuentes-Duculan J, Whynot J, Novitskaya I, Cardinale I, et al. Major differences in inflammatory dendritic cells and their products distinguish atopic dermatitis from psoriasis. J Allergy Clin Immunol (2007) 119:1210-7. doi:10.1016/j.jaci.2007.03.006

137. Novak N, Allam JP, Hagemann T, Jenneck C, Laffer S, Valenta R, et al. Characterization of Fc epsilon RI-bearing CD123 blood dendritic cell antigen-2 plasmacytoid dendritic cells in atopic dermatitis. J Allergy Clin Immunol (2004) 114:364-70. doi:10.1016/j.jaci.2004.05.038

138. Bieber T, de la Salle H, Wollenberg A, Hakimi J, Chizzonite R, Ring J, et al. Human epidermal Langerhans cells express the high affinity receptor for immunoglobulin E (Fc epsilon RI). J Exp Med (1992) 175:1285-90. doi:10.1084/jem.175.5.1285

139. Wang B, Rieger A, Kilgus O, Ochiai K, Maurer D, Fodinger D, et al. Epidermal Langerhans cells from normal human skin bind monomeric IgE via Fc epsilon RI. J Exp Med (1992) 175:1353-65. doi:10.1084/jem.175.5.1353

140. Wollenberg A, Wen S, Bieber T. Phenotyping of epidermal dendritic cells: clinical applications of a flow cytometric micromethod. Cytometry (1999) 37:147-55. doi:10.1002/(SICI)1097-0320(19991001)37:2<147::AIDCYTO8>3.0.CO;2-Y

141. Novak N, Valenta R, Bohle B, Laffer S, Haberstok J, Kraft S, et al. Fc epsilon RI engagement of Langerhans cell-like dendritic cells and inflammatory dendritic epidermal cell-like dendritic cells induces chemotactic signals and different T-cell phenotypes in vitro. J Allergy Clin Immunol (2004) 113:949-57. doi:10.1016/j.jaci.2004.02.005

142. Soumelis V, Reche PA, Kanzler H, Yuan W, Edward G, Homey B, et al. Human epithelial cells trigger dendritic cell mediated allergic inflammation by producing TSLP. Nat Immunol (2002) 3:673-80. doi:10.1038/ni805

143. Wollenberg A, Mommaas M, Oppel T, Schottdorf EM, Gunther S, Moderer M. Expression and function of the mannose receptor CD206 on epidermal dendritic cells in inflammatory skin diseases. J Invest Dermatol (2002) 118:327-34. doi:10.1046/j.0022-202x.2001.01665.x

144. Kerschenlohr K, Decard S, Przybilla B, Wollenberg A. Atopy patch test reactions show a rapid influx of inflammatory dendritic epidermal cells in patients with extrinsic atopic dermatitis and patients with intrinsic atopic dermatitis. J Allergy Clin Immunol (2003) 111:869-74. doi:10.1067/mai.2003.1347

145. Fujita H, Shemer A, Suarez-Farinas M, Johnson-Huang LM, Tintle S, Cardinale I, et al. Lesional dendritic cells in patients with chronic atopic dermatitis and psoriasis exhibit parallel ability to activate T-cell subsets. J Allergy Clin Immunol (2011) 128:574-82. doi:10.1016/j.jaci.2011.05.016

Conflict of Interest Statement: The authors declare that the research was conducted in the absence of any commercial or financial relationships that could be construed as a potential conflict of interest. The Guest Associate Editor Marianne Boes declares that, despite being affiliated to the same institution as authors Arjan Boltjes and Femke van Wijk, the review process was handled objectively and no conflict of interest exists.

Received: 30 January 2014; accepted: 14 March 2014; published online: 01 April 2014. Citation: Boltjes A and van Wijk $F$ (2014) Human dendritic cell functional specialization in steady-state and inflammation. Front. Immunol. 5:131. doi: 10.3389/fimmu.2014.00131

This article was submitted to Antigen Presenting Cell Biology, a section of the journal Frontiers in Immunology.

Copyright (C) 2014 Boltjes and van Wijk. This is an open-access article distributed under the terms of the Creative Commons Attribution License (CC BY). The use, distribution or reproduction in other forums is permitted, provided the original author $(s)$ or licensor are credited and that the original publication in this journal is cited, in accordance with accepted academic practice. No use, distribution or reproduction is permitted which does not comply with these terms. 